\title{
La comunicazione visiva nell'era digitale, tra diffusione e formazione
}

\author{
Maria Linda Falcidieno \\ Massimo Malagugini \\ Ruggero Torti
}

Abstract

Il lavoro intende affrontare il tema delle potenzialità insite nelle nuove tecnologie interattive per la rappresentazione; il riferimento non è tanto al loro utilizzo in termini di comunicazione a fini ludico-turistici, ancorché colti, quanto piuttosto al fine della diffusione della conoscenza per l'approccio progettuale o didascalico-formativo.

L'ambito di riferimento, perciò, è quello della ricerca universitaria e della conseguente 'terza missione', necessaria perché competenze specialistiche possano essere conosciute e quindi acquisite dal numero maggiore possibile di interessati.

Il campo di esemplificazione: il territorio, ovvero l'aspetto maggiormente complesso per ciò che riguarda la raccolta dati e la loro visualizzazione; argomento oggi ineludibile, a fronte della messa in discussione di molti operati antropici, vere e proprie sfide alla vocazione dell'assetto originario di un luogo. La rappresentazione - nella sua accezione di contributo visivo interattivo - appare essere il medium ideale per comparare immediatamente I 'assetto originario di un luogo - urbano o sub-urbano che sia - di norma non più visibile, perché trasformato nel tempo anche in maniera massiccia, secondo due finalità immediate: supportare le valutazioni critiche pre-progettuali e formare cittadini consapevoli della natura del loro spazio di riferimento. In tal modo il ruolo del rappresentatore diverrà supporto fondamentale e attività di pubblica utilità.

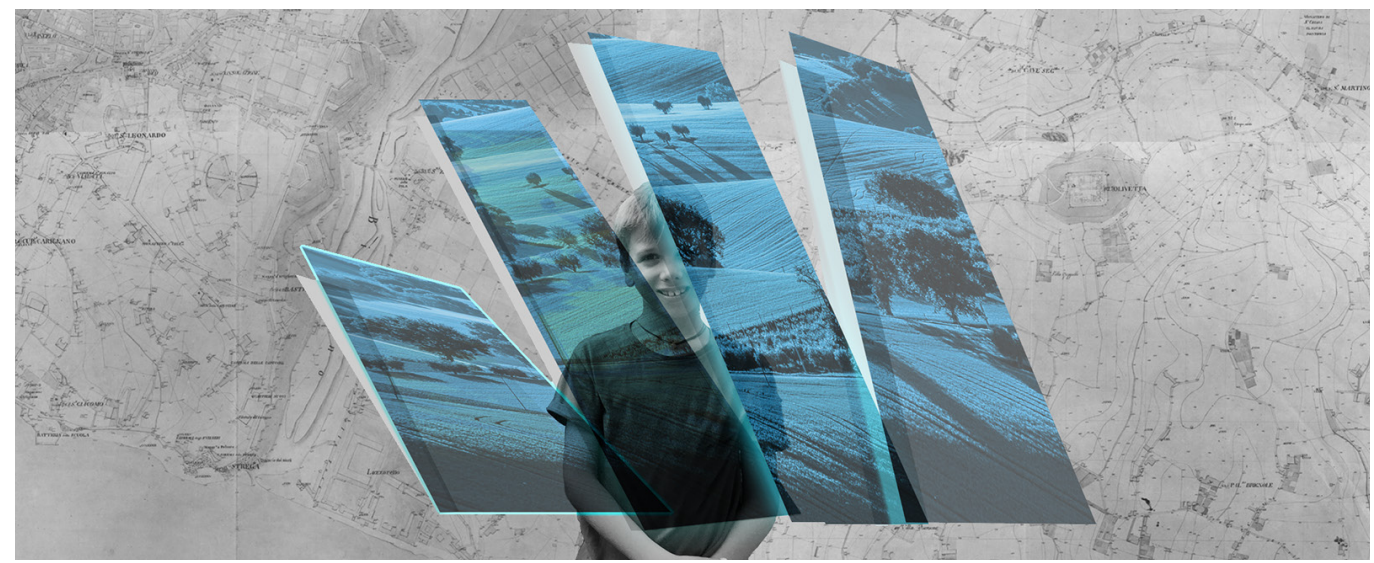




\section{Introduzione}

Se da tempo si è consolidato il pensiero che attribuisce alla comunicazione visiva il ruolo di principale alternativa alla comunicazione testuale in un mondo sempre più bisognoso di basi comuni e codici condivisi per una facilitazione dei rapporti interpersonali e sociali, in parte ancora da indagare sono le interpolazioni tra i contributi 'umanistici' e quelli 'digitali', oggi inevitabilmente a contatto e confronto continuo.

Digital humanities è fondamentalmente un ossimoro, che tuttavia rende precisamente l'idea delle nuove frontiere che si vanno delineando nella contemporaneità; e quale disciplina più della rappresentazione (o del disegno inteso in senso generale come manifestazione grafica di realtà o pensieri) vi si può identificare?

Dall'umanistica: la creatività, la percezione e la soggettività; dal digitale: tutte le possibili semplificazioni ed espansioni che in continuo divenire aprono alla rappresentazione e alle sue molteplici accezioni nuove frontiere espressive, conoscitive, applicative. Oggi sembra necessario provare a mettere a punto almeno qualche concetto di base, che possa essere utile a comprendere sfaccettature, accezioni e ambiti operativi.

Uno dei campi di maggiore e proficua sperimentazione in tal senso è dato dall'aggiornarsi del mondo universitario, attraverso la nuova articolazione della sua missione: se primo obiettivo dell'Università era quello di trasmettere il sapere - di per sé legato al progredire delle conoscenze e, quindi, alla ricerca - da tempo i due filoni hanno raggiunto la piena equiparazione, portando alla formazione di docenti/ricercatori. Ma recentemente i pilastri fondativi sono divenuti tre, ovvero didattica, ricerca e terza missione. Locuzione, quest'ultima, per molti ancora oggi vista con diffidenza, scetticismo, rassegnazione o - peggio - vissuta e subita come depauperamento del sapere e coercizione amministrativa, come testimonia la poca letteratura specifica relativa proprio alle sue potenzialità [I].

II contributo che si presenta prende avvio da alcune sperimentazioni attuate per progetti di ricerca, che sono proprio sfociati in applicazioni pertinenti alla terza missione universitaria, di comunicazione, divulgazione, crescita culturale e auto-formazione, apertura dei saperi

Fig. I. Impostazione del reticolo di base per la realizzazione del "puzzle" del confronto fra la cartografia di Ignazio Porro (I 835 ca.) e l'orto-fotocarta dello stato attuale di una porzione del territorio genovese.
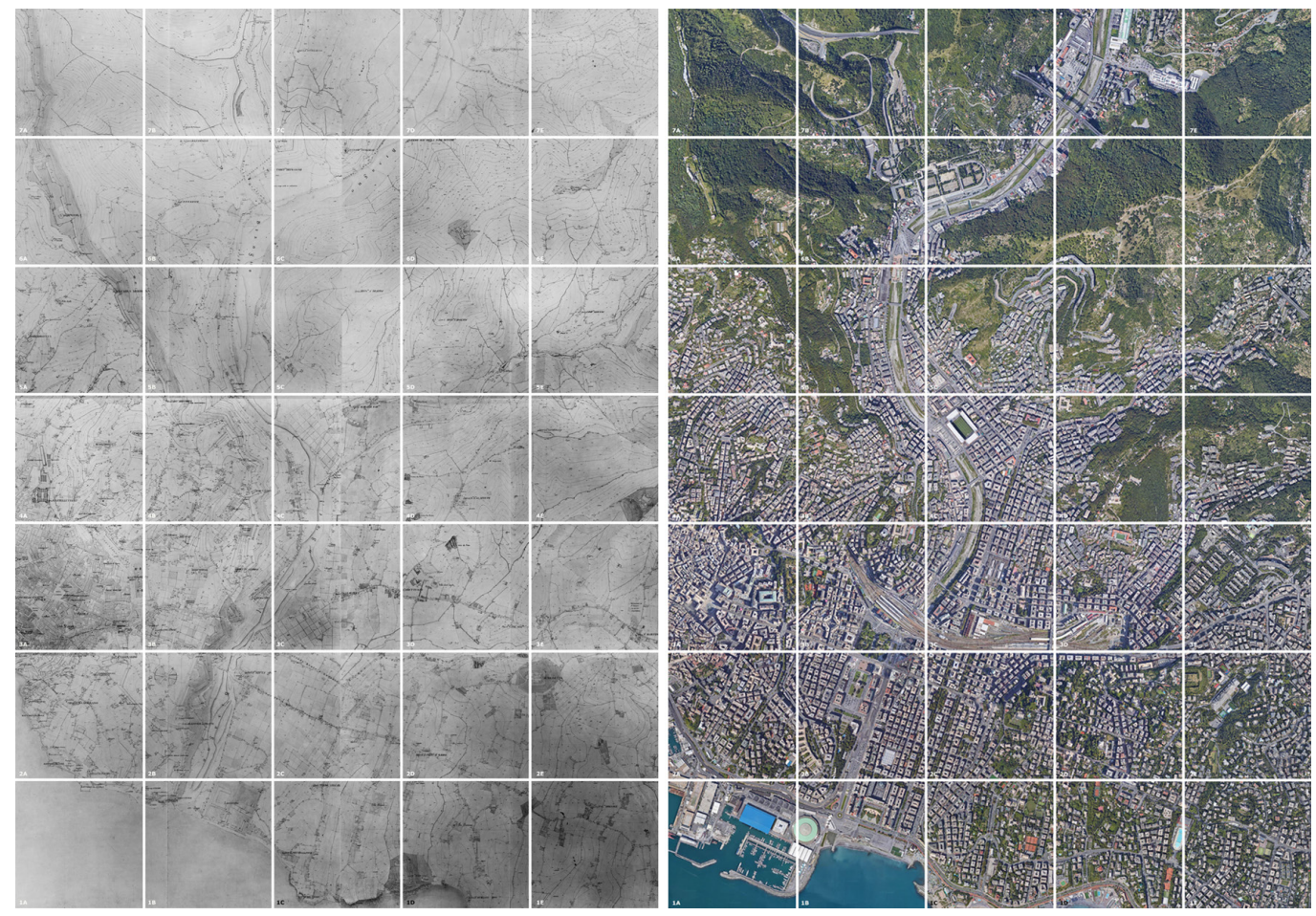
specialistici alla collettività, sia essa scolarizzata, sia ancora in formazione o anche semplicemente aperta alla conoscenza.

Fondamento comune e trasversale l'interattività, la possibilità di partecipare e contribuire alla verifica di forme comunicative efficaci e mirate, con la conseguente messa a punto di linguaggi visivi dedicati e specifici al target di riferimento, nonché l'utilizzo di tecniche analogiche e digitali; proprio le digital humanities si configurano, quindi, come potenziali metodologie di validità generale, condivisibili e reiterabili in contesti anche profondamente diversi tra loro per contenuto, basate sulla compresenza di suggestioni e sollecitazioni visive.

Il primo esempio fa riferimento alla collaborazione che da tempo è in atto con Protezione Civile e, più precisamente, con la presenza al Festival della Scienza che ogni anno si tiene a Genova; in tale sede, il gruppo di ricerca del $\mathrm{dAD}$ ha presentato un progetto relativo alla divulgazione della conoscenza del territorio di riferimento e delle sue potenzialità e fragilità. Dall'approccio analogico, alla partecipazione interattiva multimediale, nella logica delle digital humanities, per comunicare a target con differenti livelli di scolarizzazione attraverso linguaggi visivi mirati.

Il secondo esempio è anch'esso collegato all'interazione tra il digitale e l'analogico e soprattutto - tra l'approccio istintivo-soggettivo e quello codificato-oggettivo; campo di azione, questa volta, un target scolarizzato o di alta formazione, ben esemplificato dalla sala interattiva di Fondazione Ansaldo, argomento trattato nel terzo paragrafo, che si pone quale spunto e sollecitazione per l'utilizzo delle ICT al fine di una progettualità adatta a soddisfare i requisiti della terza missione universitaria.

Ciò che preme far emergere in questa sede è la non banalizzazione dei linguaggi visivi per la comunicazione e la divulgazione della conoscenza che deriva dalle ricerche universitarie, ottenuta con un equilibrato e corretto rapporto tra i due differenti approcci: non solo divertissements che rendano gradevole e maggiormente facile l'approccio alla conoscenza, ma veri e propri strumenti di lavoro e studio, che coinvolgano attraverso la partecipazione attiva e responsiva, atto fondamentale per una continua verifica da parte dei ricercatori della correttezza delle proprie scelte per la diffusione del sapere.

Fig. 2. Individuazione degli elementi di riferimento per la sovrapposizione $e$ per la collimazione della cartografia di Ignazio Porro (1835 ca.) con la cartografia attuale.
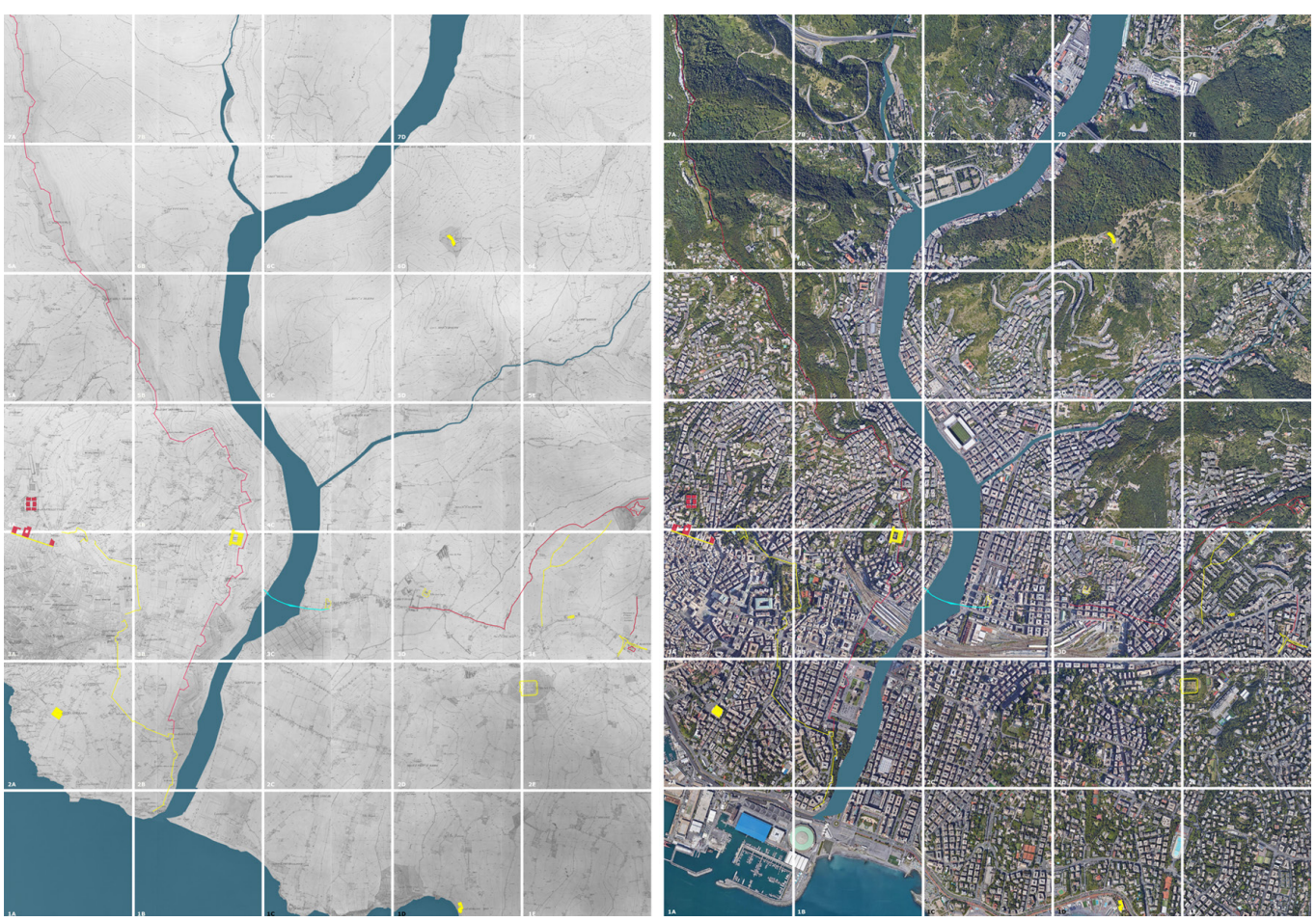


\section{L'esperienza in protezione civile}

La proficua e continuativa collaborazione fra il dAD (Dipartimento Architettura e Design dell'Università degli studi di Genova) e il Servizio genovese di Protezione Civile ha messo a punto, in questi ultimi anni, un efficace sistema di comunicazione nel quale il disegno (sempre inteso in senso generale come una manifestazione grafica) ha giocato un ruolo di primaria importanza [2]. La necessità di comunicare a target differenziati la cultura di Protezione Civile, strettamente connessa alla conoscenza del territorio, alla sua fragilità e alla sua resilienza, unitamente alla necessità di formare una coscienza circa le buone pratiche da adottare in caso di eventi calamitosi, ha consolidato ulteriormente questa collaborazione chiamando in causa una serie di competenze che - storicamente e istituzionalmente - sono sempre appartenute alle discipline della rappresentazione. In particolare, si fa riferimento alla rappresentazione del territorio che da sempre si è avvalsa di codici e convenzioni grafiche per riuscire a descrivere con immediatezza ogni tipo di caratteristica morfologica o antropica.

Una straordinaria occasione per dare risposta concreta a quella terza missione universitaria, che dovrebbe mirare alla comunicazione e alla divulgazione integrando le conoscenze specialistiche per diffondere la cultura alla collettività, ha preso forma in occasione dell'ultima edizione del Festival della Scienza [3], nella quale il progetto presentato è stato selezionato per sviluppare un laboratorio che riuscisse a diffondere la consapevolezza di come si è evoluta la città fino a modificare l'originario assetto naturale. In questo senso, la rappresentazione è diventata il mezzo necessario per visualizzare le variazioni della forma della città e del suo territorio. Le esperienze condotte in questi anni di collaborazione con Protezione Civile hanno permesso di mettere a fuoco un laboratorio interattivo - rivolto non soltanto ai ragazzi - che si basasse sul riconoscimento dei luoghi attraverso la rappresentazione cartografica e fotografica secondo un percorso cronologico che mettesse in evidenza il processo evolutivo ed espansivo della città e del suo territorio.
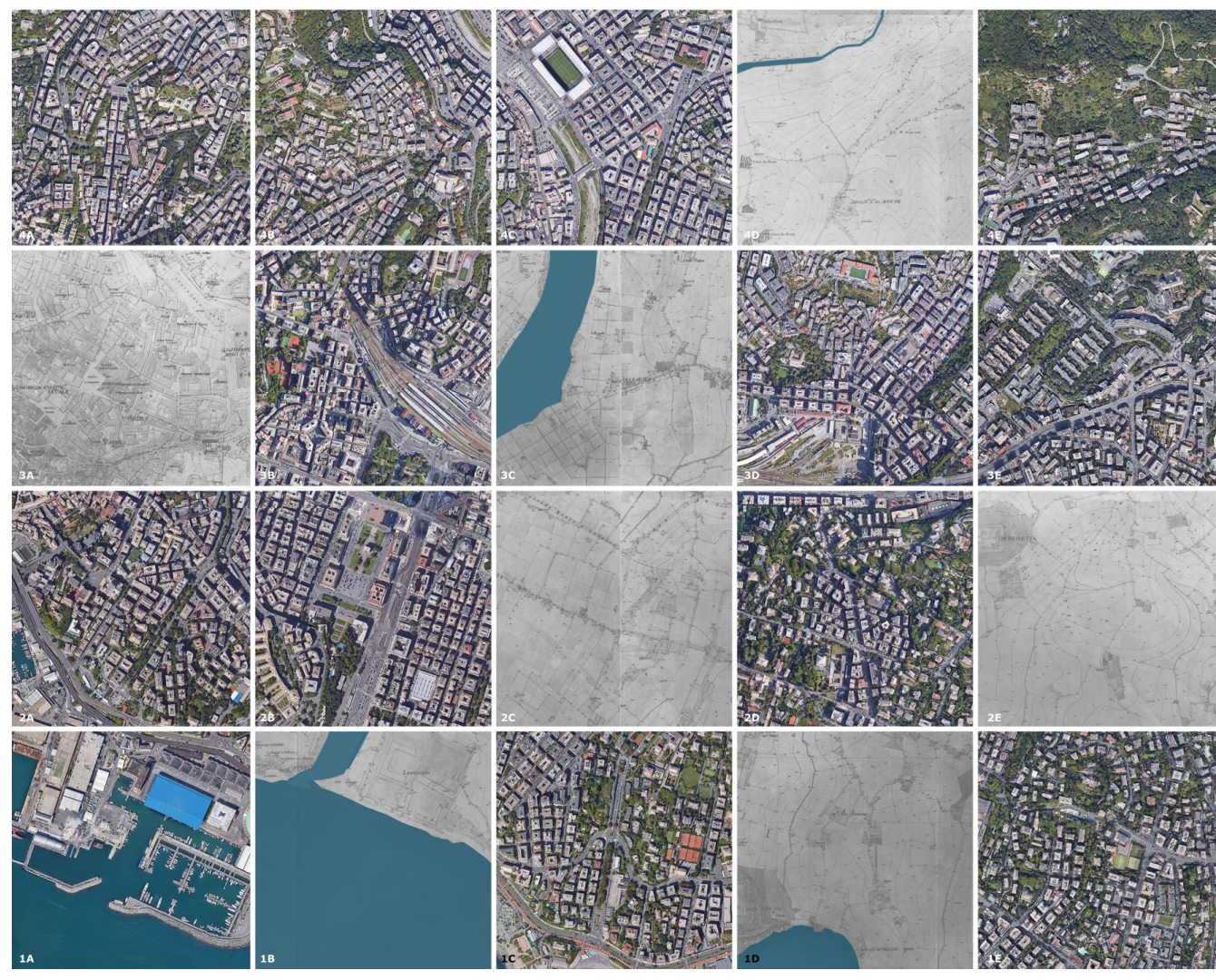
Per raggiungere tale obiettivo si è fatto affidamento sui tradizionali sistemi di rappresentazione cartografica, realizzando un grande tappeto che riportava un ingrandimento della rappresentazione della città secondo il rilievo topografico redatto da Ignazio Porro nella prima metà dell'Ottocento [4]; a questo si sono sovrapposti dapprima un supporto trasparente che mettesse in evidenza alcuni tratti della morfologia del territorio e, successivamente, un vero e proprio puzzle le cui tessere ricomponevano l'immagine ortofotografica attuale di quello stesso territorio. La sovrapposizione delle tessere raffiguranti lo stato attuale sulla cartografia storica ha consentito di visualizzare con immediatezza i grandi interventi antropici che hanno modificato l'assetto urbanistico e territoriale causando in alcuni casi la perdita dell'identità originaria dei luoghi e, in altri, alterando la naturale resilienza del territorio stesso. II laboratorio ha permesso di comprendere come l'antropizzazione del territorio implichi necessariamente una presa di coscienza circa le possibili conseguenze che da essa potrebbero derivare e, dunque, di capire quali ulteriori azioni sia necessario mettere in atto in particolari circostanze od eventi calamitosi.

L'approccio sperimentale a questo tipo di attività didattico-laboratoriale ha aperto un filone di ricerca che si avvale degli attuali strumenti digitali per fornire informazioni sempre più specifiche e dettagliate, fino a giungere alla lettura delle singole componenti territoriali, siano esse naturali (corsi d'acqua ora coperti), architettoniche (edifici trasformati o sostituiti nel tempo), produttive (aree oggi dismesse). In senso più generale, si tratta di estendere questo tipo di lettura critica del territorio attraverso la sua rappresentazione interattiva ad un bacino più ampio di utenti (non soltanto scuole, ma istituzioni, altri enti formatori, etc.) utilizzando sistemi digitali che, partendo dalla rappresentazione virtuale dello stato attuale della città, possano visualizzarne con immediatezza il processo evolutivo, descrivendo una sorta di time-lapse dell'evoluzione della città e del suo territorio, modulata in relazione alle differenti esigenze dell'utente in questione. Si potranno, allora, visualizzare nel dettaglio alcune fasi dell'intero processo evolutivo; prendere visione di mutazioni di una particolare porzione del territorio; attuare in ogni momento un confronto con la fase più evoluta (stato attuale), fino a proiettare le possibili mutazioni che sono ancora in divenire: in breve, si potrà dotare il vasto numero di operatori a vario titolo interessati di uno strumento di semplice utilizzo, ma di alto potenziale conoscitivo e operativo, utile a verificare e rispondere anche a quesiti progettuali.

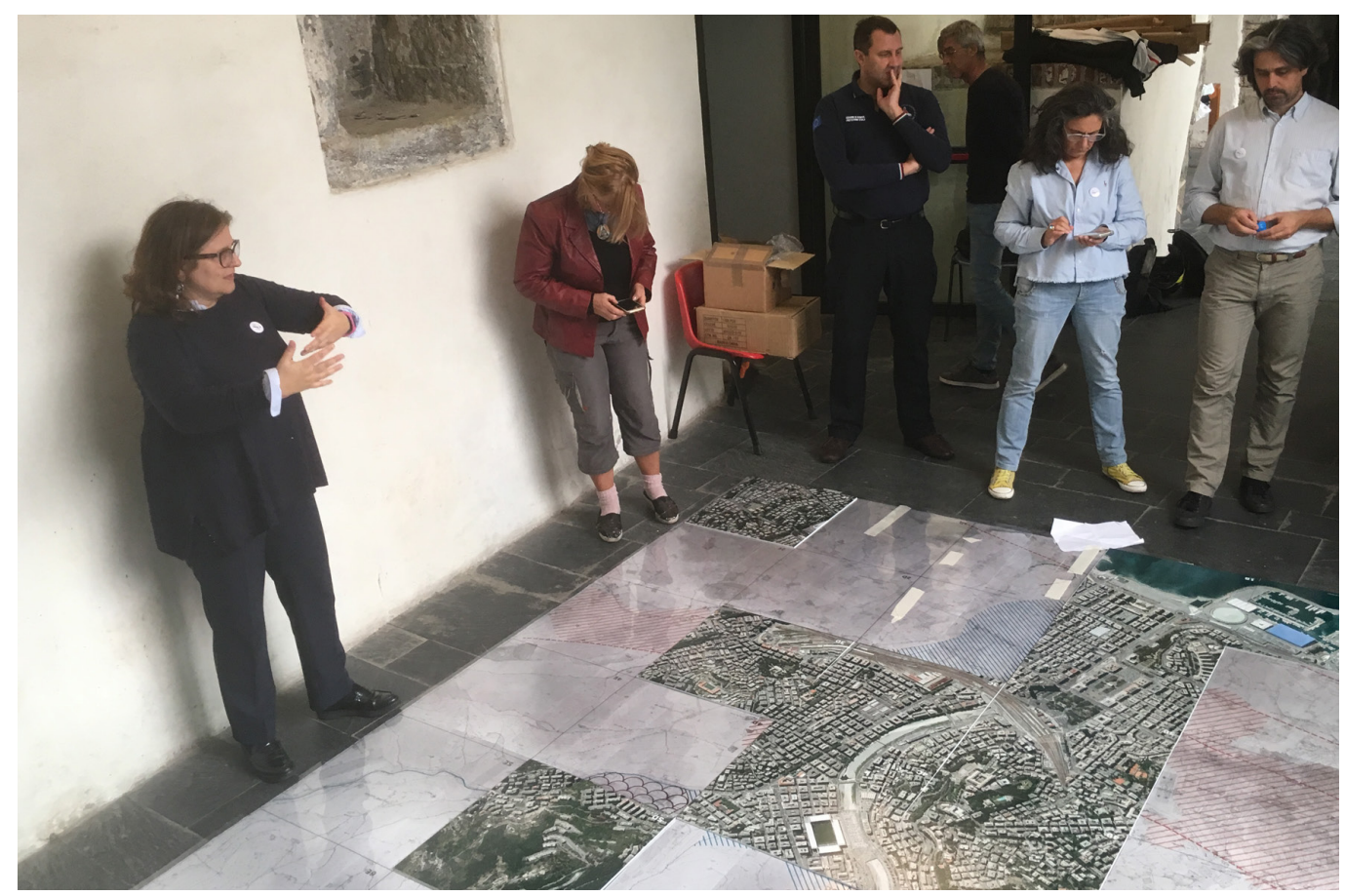




\section{Experience: nuove opportunità del rappresentare}

Da quanto finora affermato sul concetto di integrazione dei sistemi analogici e interattivi, emerge come il vivace dibattito contemporaneo sulle potenzialità date dalle continue evoluzioni tecnologiche porti sempre più alla ricerca dell'integrazione dei sistemi AVC (Audio, Video e Controlli), del Lighting, del Networking dell'ICT; tale ibridazione è oggetto, quindi, di una sempre più crescente attenzione da parte di interlocutori diretti e indiretti che persino non possedendo specifiche conoscenze e competenze tecnologiche dei temi - si trovano coinvolti nel sistema, alla ricerca di nuove opportunità e di differenti modalità del rappresentare a fini mirati, quali il conoscere il passato per progettare il futuro, informare e formare una società consapevole delle potenzialità e rischi del territorio di appartenenza, generare esperienze.

In questa sede l'obiettivo non risiede, quindi, nel definire e divulgare le caratteristiche tecniche, i protocolli, i formati e le risoluzioni presenti nelle tecnologie più attuali e sofisticate al servizio della rappresentazione ma, al contrario, nel diffondere le potenzialità che queste tecnologie sono in grado di offrire, per attuare e soprattutto ispirare soluzioni per situazioni anche problematiche in continuo divenire. Queste innovative frontiere digitali di comunicazione visiva sono capaci, infatti, di ideare nuovi modi di visualizzazione del contesto e generare interazione tra gli utenti e le tecnologie stesse, in maniera estremamente duttile rispetto alle finalità, che possono - come detto in precedenza - essere anche molto differenti tra loro. Da qui la decisione di condividere due esperienze concrete da vivere in prima persona sia come protagonisti, sia come utenti finali.

A tal proposito, i due esempi applicativi - la sala multimediale della Fondazione Ansaldo di Genova [5] e la rappresentazione di contenuti $3 d$ tramite proiezioni olografiche - rientrano in un percorso di ricerca e in approfondimenti espressi sia in sede di Master e Dottorato, sia durante la recente esperienza didattica in Cina alla Beijing University of Chemical Tecnology [6]. Nella loro diversità comunicativa queste due esperienze sono accumunate dall'elevato contenuto tecnologico e dalla capacità di interazione immediata.

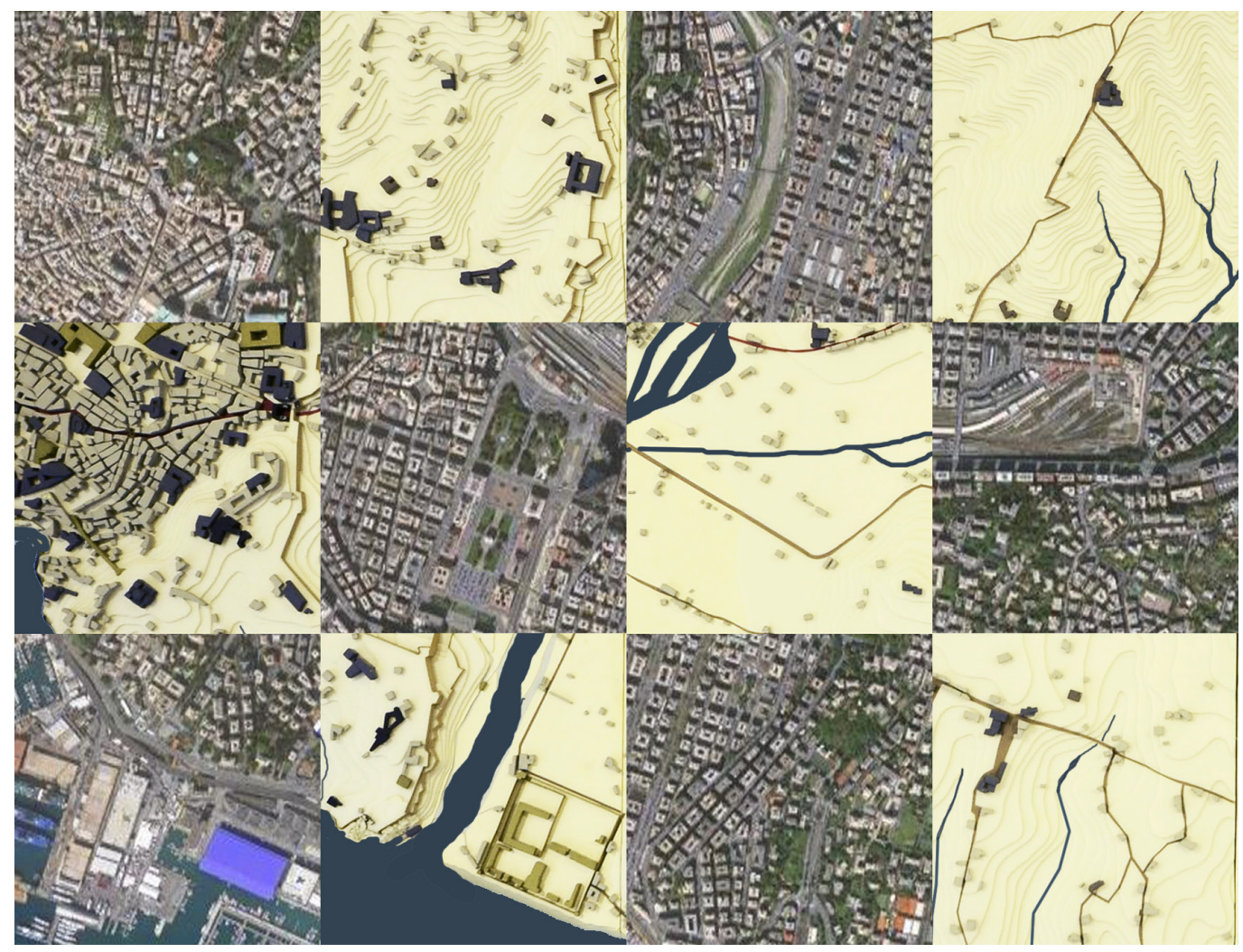


Nello specifico, l'installazione multimediale presente presso la sede della Fondazione Ansaldo di Genova si avvale della videoproiezione su un grande schermo di immagini d'archivio che 'raccontano' il mutare di uno scorcio di territorio genovese attraverso una rappresentazione videografica di grande impatto, capace di trasporre in linguaggio visivo il valore intrinseco di documenti, storie e contesti. L'utente viene avvolto in una suggestiva ambientazione - volutamente poco illuminata per esigenze tecniche - caratterizzata dalla presenza di un sofisticato sistema di videoproiezione e da una serie di torce elettriche a disposizione dei visitatori. Al semplice passaggio del fascio luminoso emesso dalla torcia elettrica comandata dal fruitore, le fotografie storiche in bianco e nero - connotanti il paesaggio urbano del $X X$ secolo oggi sovente non più riconoscibile nel suo aspetto originario - lasciano il posto alle colorate e attuali fotografie degli stessi luoghi perfettamente sovrapposte alle precedenti, evidenziando immediatamente le differenze tra le immagini appartenenti al passato con l'aspetto attuale e reale della città. II passaggio del fascio luminoso infatti, 'annulla' la proiezione dell'immagine storica - in quanto sensibile alla luce - cancellandone il contenuto; solo in quella precisa porzione di area illuminata dalla torcia, perciò, si evidenzia l'immagine a colori presente su un 'livello' sottostante. Naturalmente, l'inserimento dell'immagine storica in primo piano e dell'immagine attuale su un livello sottostante può essere invertito a seconda delle necessità comunicative.

La seconda esperienza, invece, si lega alla recente rivoluzione tecnologica al servizio della creatività digitale in grado di offrire innumerevoli possibilità: il Pixel Mapping, basata sul controllo di luci, led strip e sofisticate apparecchiature hardware e software per ottenere l'interazione tra la terza dimensione e il lighting. Questa tecnica infatti, fonde le proprie basi sulla traduzione delle informazioni da pixel a RGB; come nelle tecniche di rappresentazione olografiche progettate per riprodurre fluttuanti ologrammi 3d, ricopre un ruolo fondamentale la controllata collocazione spaziale delle luci, generatrice della componente tridimensionale. II display olografico, infatti, è un dispositivo costituito da un rotore a quattro pale su ognuna delle quali è collocata una striscia di led che, girando ad alta velocità, riesce a riprodurre ologrammi in movimento. Le uniche accortezze risiedono nello scaricare la App e abbinare il proiettore olografico al proprio smartphone, tablet o pc in maniera da permettere il dialogo e la trasmissione in Wi-Fi dei contenuti dal nostro device al display olografico. Le informazioni che vogliamo generare per poi trasmetterle al proiettore ologra-

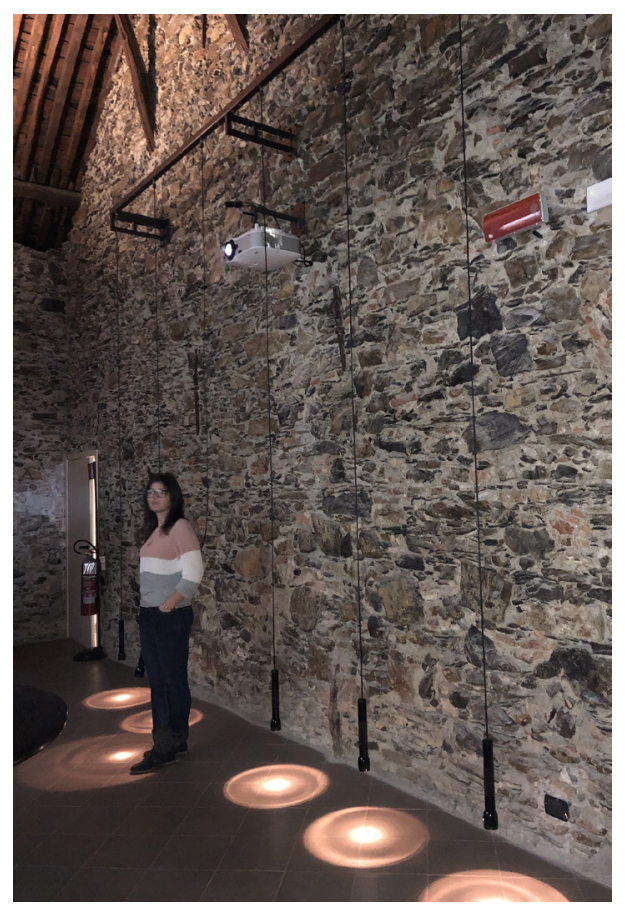




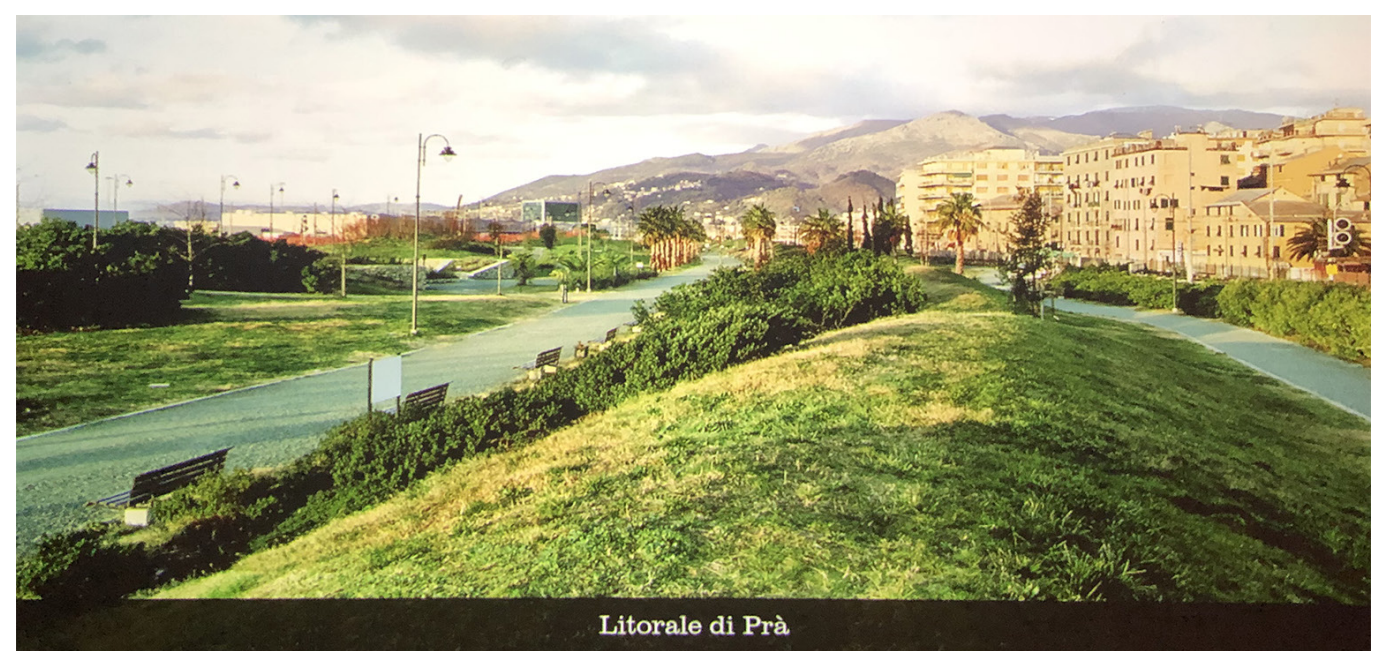

Fig. 7. Sequenza di

immagini proiettate su

un grande schermo che

'raccontano' il mutare di

uno scorcio di territo io

attraverso una rappre-
sentazione videografica d grande impatto.
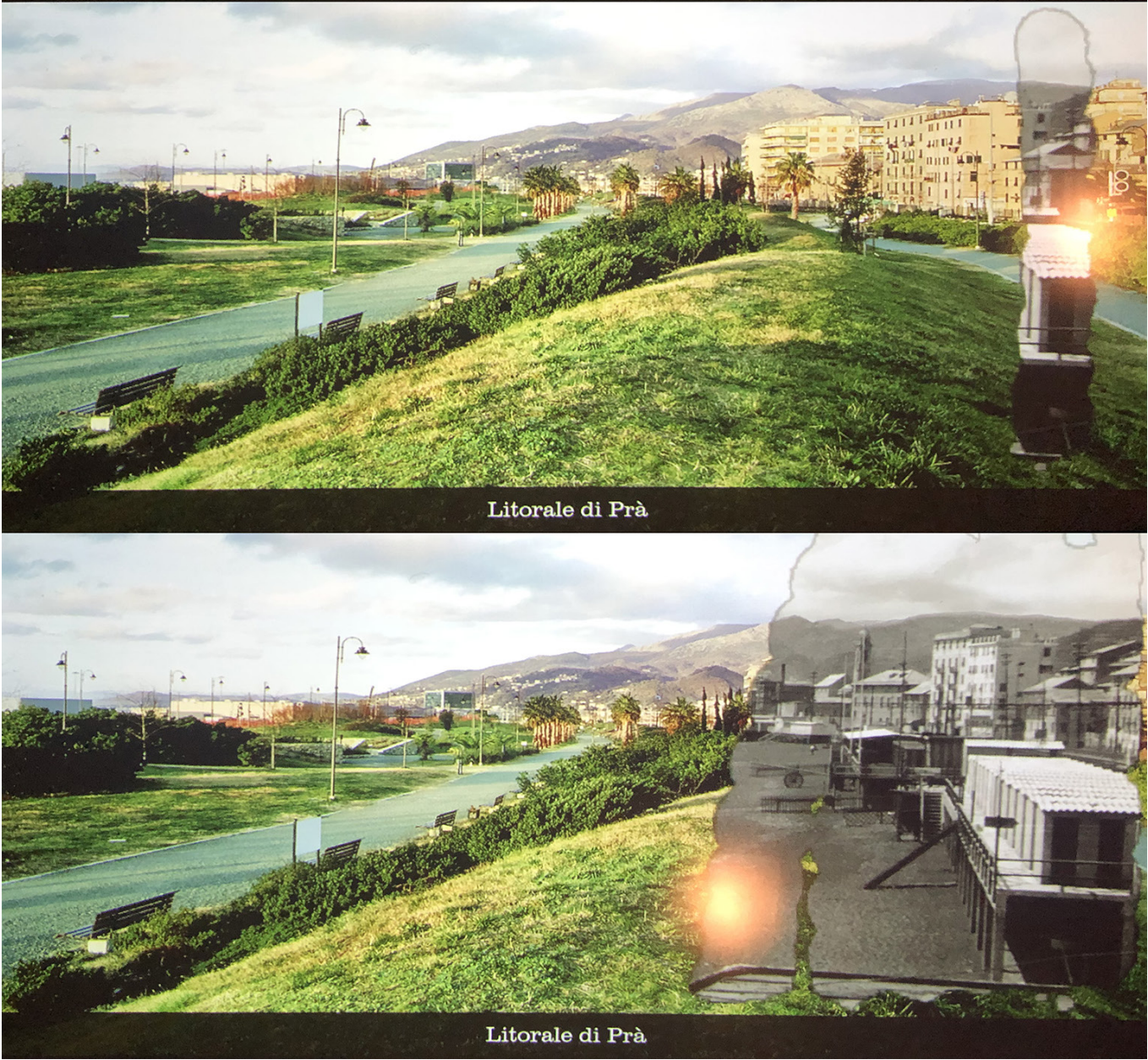


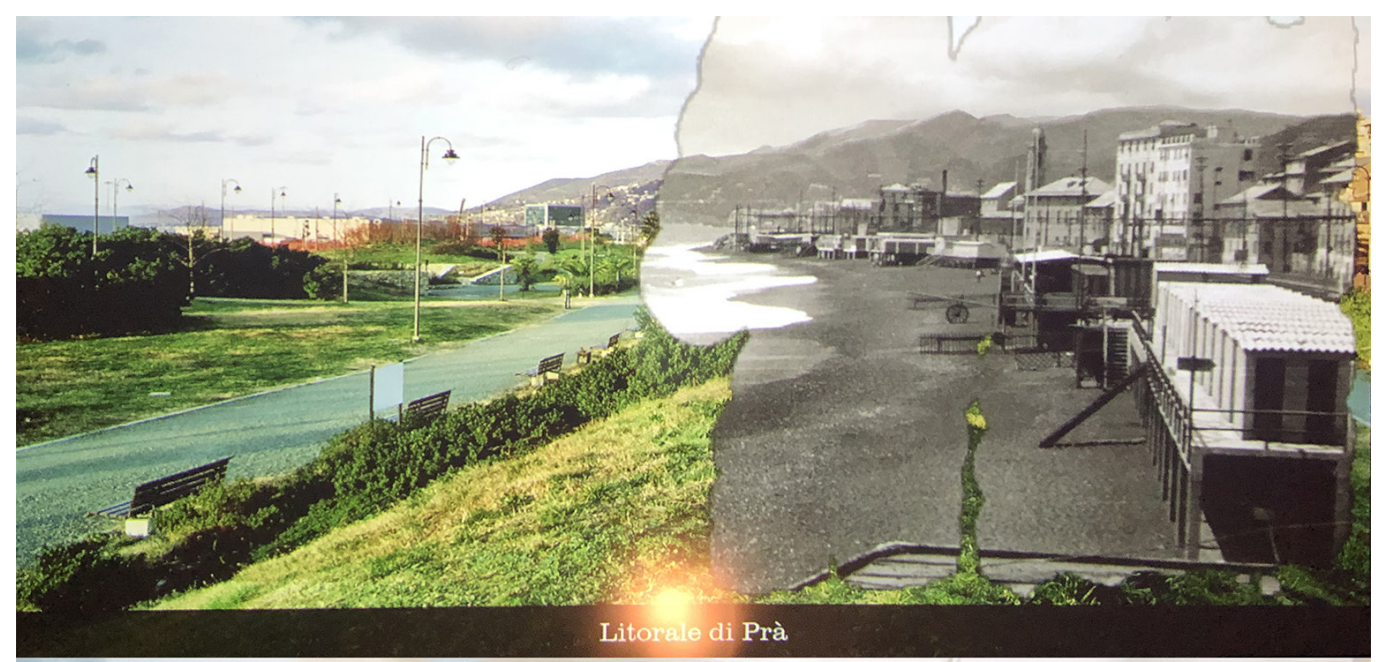

Fig. 8. II fascio luminoso emesso dalla torcia ettrica comandata dal fruitore cancella atuali fotografie a colori m mmagini storiche in bianco e nero connotant il paesaggio urbano de X secolo degli stessi

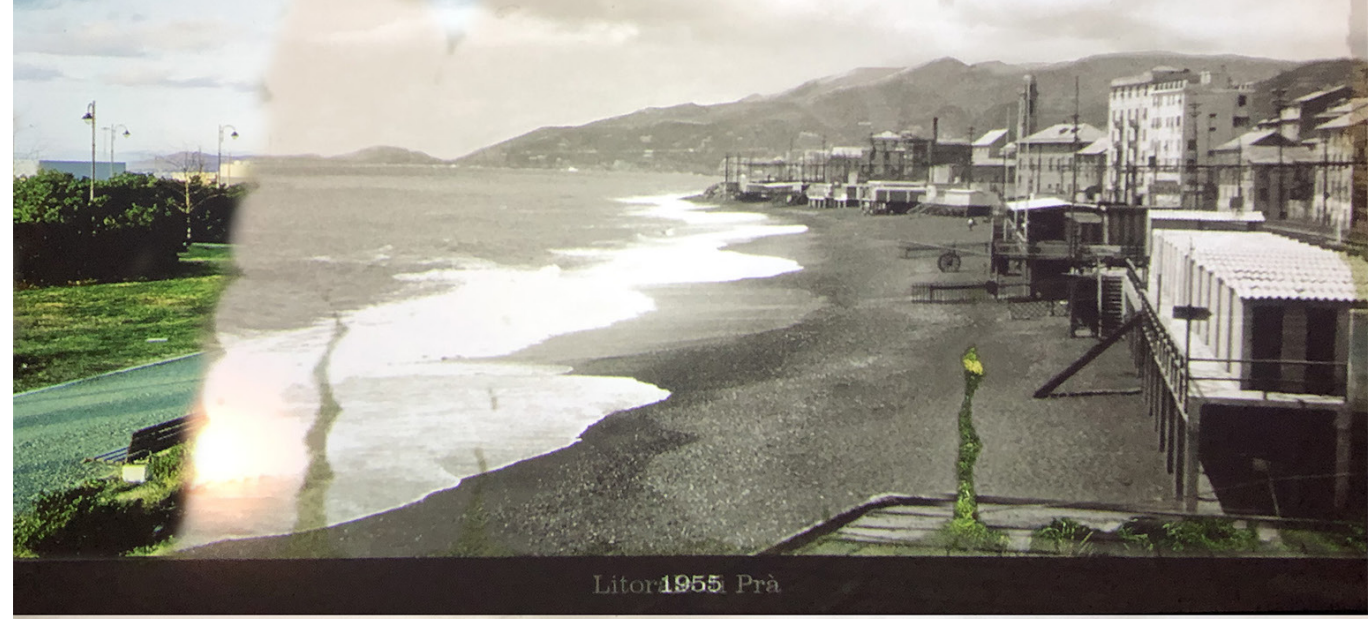
uoghi.

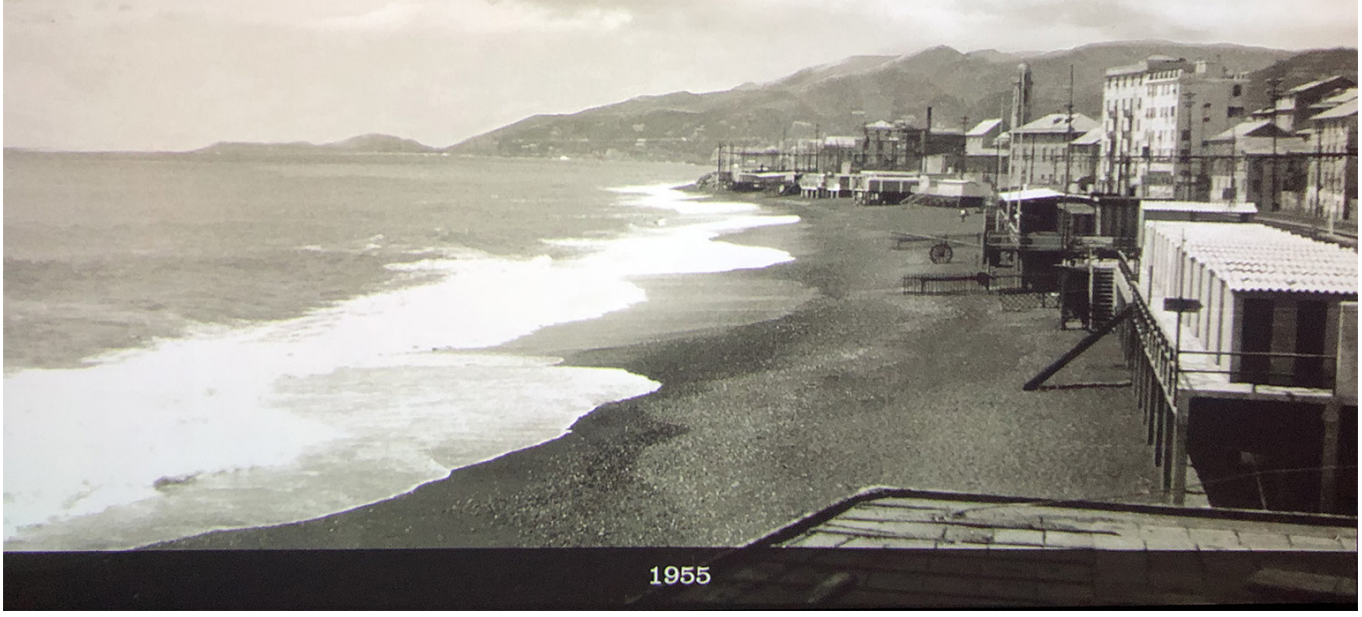


Fig. 9. Sequenza di immagini rappresentanti una fase di montaggio di un display olografico costituito da un rotore a quattro pale su ognuna delle quali è collocata un striscia di led; l'unione di più rotori "Wall" in grado diu rotor "Wall in grado 3d tenere ologramm cion sili, interfaccia utente della App scaricata su smartphone e abbinat al proiettore olografico per la trasmissione in WiFi dei contenuti $3 d$ da proiettare.

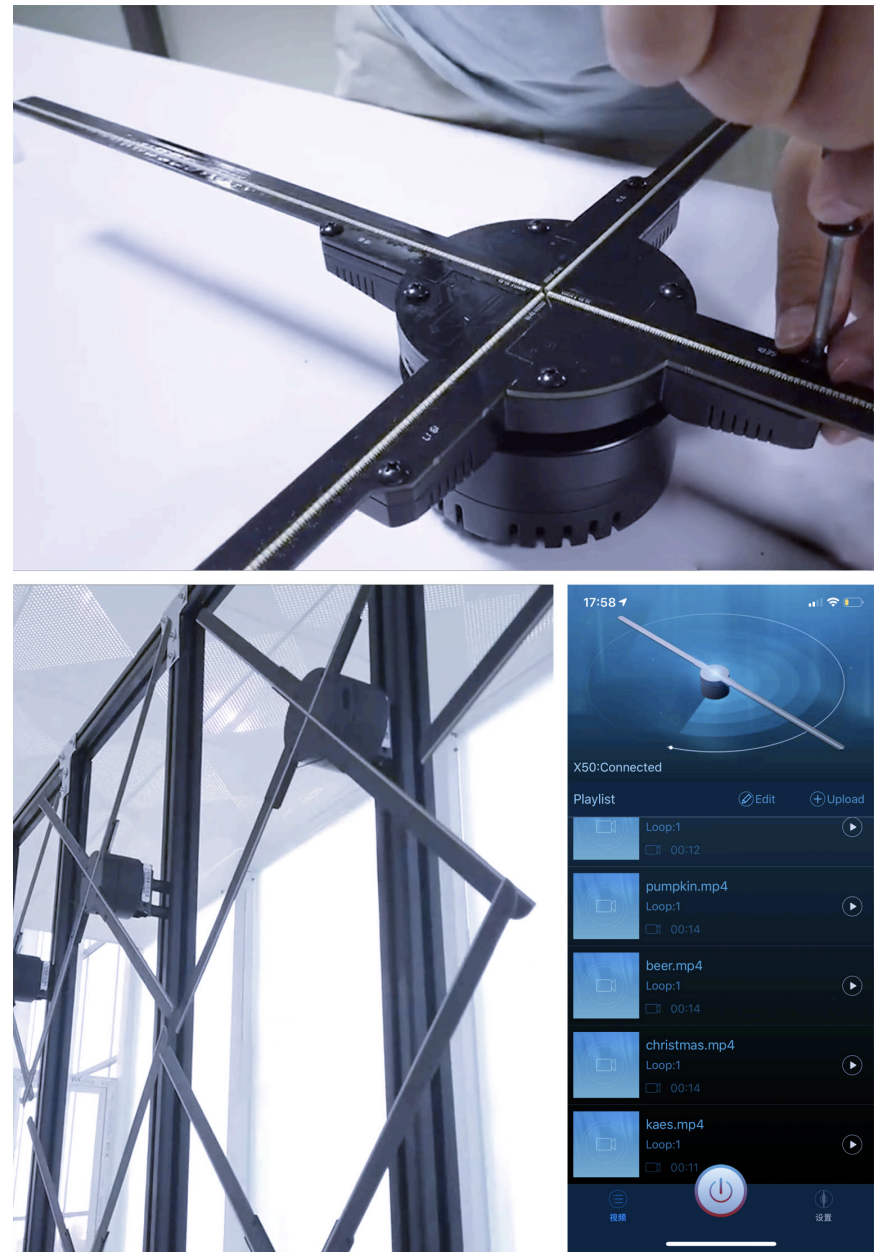

fico - indipendentemente che siano testi, immagini, video o modelli virtuali $3 \mathrm{~d}$ - richiedono il salvataggio in .jpeg, .mp4, .mov e altri formati standard. I singoli dispositivi sono installabili a parete, a soffitto, a pavimento o inglobati in totem e l'unione di più rotori costituisce un wall in grado di ottenere ologrammi $3 \mathrm{~d}$ di maggiori dimensioni ad alta risoluzione, capaci di generare esperienze immersive.

II punto di forza di tali forme di rappresentazione - interattive o immersive che siano risiede nel coinvolgimento dell'utente e rende queste tecnologie versatili e fortemente comunicative, in grado di promuovere conoscenza a vari livelli; nello specifico, permettono di avvicinarsi al territorio in maniera critica per produrre conoscenza anche in chi non ne conosce il passato, formando, quindi, potenziali operatori e utenti consapevoli.

In conclusione, siamo fruitori e artefici di un sempre più evoluto progresso tecnologico, fautore di un epocale cambiamento delle tecniche di rappresentazione per la diffusione di informazioni che, pur affiancando i metodi e gli strumenti tradizionali basati sulla visualizzazione tridimensionale attraverso supporti bidimensionali come i monitor, si impongono sulla scena attraverso dispositivi digitali in grado di riprodurre nel mondo reale dei contenuti olografici $3 \mathrm{~d}$ di notevole impatto, percepibili senza l'ausilio di visori o di devices; l'importanza di una simile possibilità è facilmente comprensibile quando, ad esempio, si pensi alla necessità di formare gruppi di persone, illustrare limiti e potenzialità in vista di interventi progettuali o far toccare con mano la fragilità di un territorio apparentemente solido.

Le esperienze dirette delle tecniche multimediali oggi a disposizione e del loro potenziale possono essere quindi sintetizzate in una parola chiave: Experience [7], quale inizio e fonte di ispirazione di nuovi progetti, frutto dell'evoluzione del settore e del cambiamento della società attuale sempre più connessa e supportata dalle tecnologie informatiche [8]. 

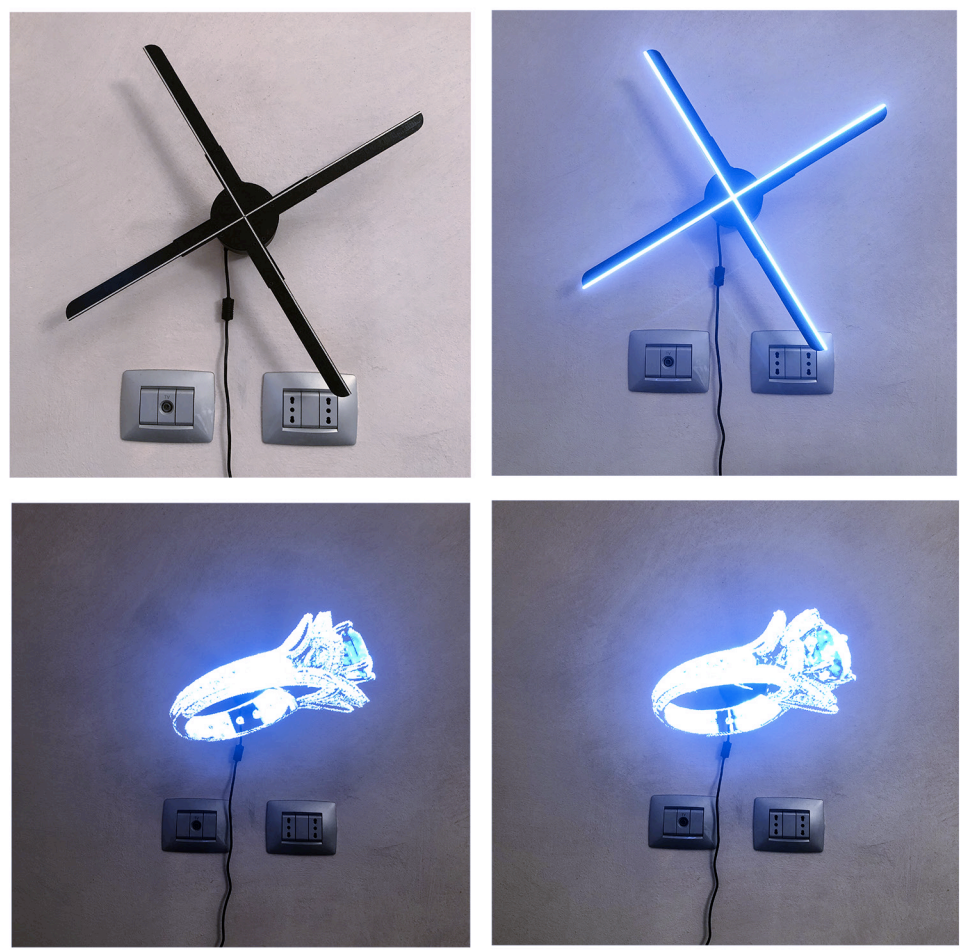

Fig. I0. Raffigurazione del funzionamento del display olografico in grado riprodurre contenuti $3 \mathrm{~d}$ nel mondo reale, percepibili senza l'ausilio di visori o di devices.
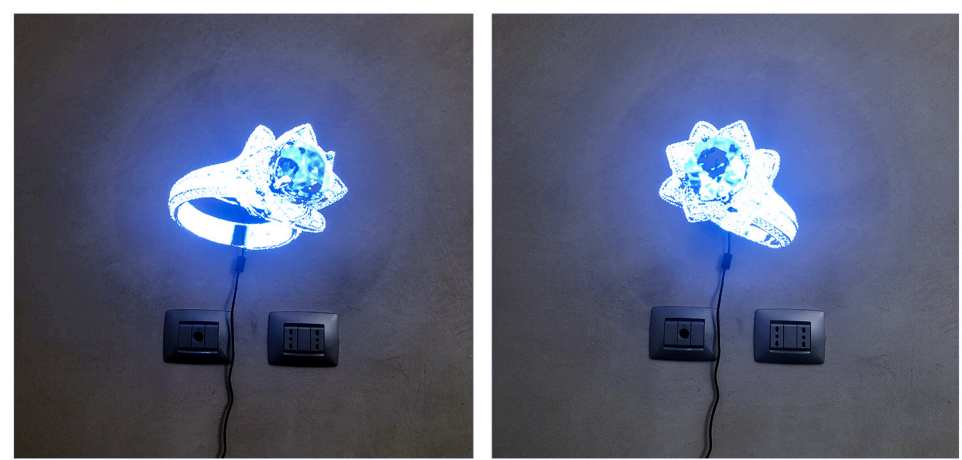

\section{Note}

[I] Se da un lato è indubbia la carenza di trattazioni scientifiche specifiche sulla terza missione, dall'altro occorre sottolineare come comunque molti spunti e considerazioni derivino dalla ricca e articolata letteratura che riguarda il contributo delle nuove tecnologie interattive applicate al Cultural Heritage, così come le sperimentazioni di comunicazioni a scopi culturali tramite realtà virtuale, aumentata o mista (cfr. bibliografia), riletti e interpretati alla luce della finalità specifiche dell'Università.

[2] La collaborazione pluriennale svolta fra il Dipartimento e Protezione Civile del Comune di Genova ha preso il via dalla necessità di definire e promuovere una riconoscibile identità visiva per la comunicazione di pubblica utilità. II lavoro di ricerca ha trovato applicazione nelle numerose campagne di comunicazione e nella programmazione e realizzazione di una serie di eventi rivolti a target distinti ed è stato in parte esposto nel volume Emergenze ambientali e sociali: nuovi modelli di comunicazione visiva, Genova University Press, 2019.

[3] II festival della Scienza, organizzato dal Comune di Genova che giungerà quest'anno alla sua XVIII edizione, è un punto di riferimento per la divulgazione della scienza, nonché un'occasione di incontro per ricercatori, appassionati, scuole e famiglie, grazie ad una serie di Incontri, laboratori, spettacoli e conferenze per raccontare la scienza in modo innovativo e coinvolgente, con eventi interattivi e trasversali. Ad oggi è considerato uno dei più grandi eventi di diffusione della cultura scientifica a livello internazionale.

[4] La cartografia di Ignazio Porro, realizzata sulla base del rilievo strumentale eseguito negli anni '30 del XIX secolo, rappresenta uno strumento straordinariamente attendibile per la conoscenza del territorio genovese (e del relativo edificato) prima dei grandi stravolgimenti urbanistici ottocenteschi.

[5] L'esperienza di Fondazione Ansaldo risale al 2004 e ha portato alla verifica dell'efficacia della tecnica impiegata dallo studio N!03 - basata su un sistema di luci a infrarosso rilevate da un apposito software -, ma anche al problema del mantenimento e dell'aggiornamento, una volta chiuso il rapporto con gli operatori-progettisti; pertanto, oggetto di ricerca attuale è la possibilità di trasformare l'allestimento - frutto di un programma non più in commercio - in uno analogo, ma supportato da hardware e software compatibili con una gestione interna all'azienda. 
[6] L'interazione tra il digitale e l'analogico e le innovative frontiere tecnologiche di comunicazione visiva sono state oggetto di argomentazione, ricerca e confronto durante il Master universitario: Scrittura Creativa e produzione di contenuti digitali presso l'Università degli Studi di Genova e nei Seminari di Studi Transversal Seminars: Modelli analogici e digitali: strumenti e metodi per la comunicazione digitale, svolto nell'ambito della Scuola di Dottorato in Architettura e Design, della Scuola Politecnica e Dall'analogico al digitale. La rappresentazione al servizio della comunicazione visiva svolto nell'ambito del Digital Humanities Comunicazione e nuovi media, Campus di Savona, Università degli Studi di Genova.

[7] Tale definizione deriva dal concetto di experience design riconducibile a Nathan Shedroff, il quale sostiene l'importanza dell'interazione tecnologica e dell'integrazione dei sistemi capaci di generare esperienze significative ed emozionali [Shedroff $2001]$.

[8] Maria Linda Falcidieno ha scritto il paragrafo Introduzione; Massimo Malagugini ha scritto il paragrafo L'esperienza in protezione civile; Ruggero Torti ha scritto il paragrafo Experience: nuove opportunità del rappresentare.

\section{Riferimenti bibliografici}

Apollonio Fabrizio Ivan (20 2). Architettura in 3D. Modelli digitali per i sistemi cognitivi. Milano: Bruno Mondadori.

Brusaporci Stefano (2018). Advanced Mixed Heritage: A Visual Turn Through Digitality and Reality of Architecture. In International journal of computational methods in heritage science, vol. 2, pp. 40-60.

Calvano Michele, Wahbeh Wissam (2014). Disegnare la Memoria. L'immagine della città attraverso la rappresentazione integrata - Drawing the Memory. The image of the city through the integrated representation. In DisegnareCon, vol. 7, n. I3, pp. $\mid-12$.

di Luggo Antonella, Zerlenga Ornella., Pascariello Maria Ines (2016). Rappresentazione e comu- nicazione del paesaggio tra tradizione e innovazione. In Capano Francesca, Pascariello Maria Ines, Visone Massimo (a cura di). Delli Aspetti de Paesi-Vecchi e nuovi Media per I'Immagine del Paesaggio, Vol II. Napoli: Cirice.

Falcidieno Maria Linda (2009). Comunicazione e rappresentazione. Firenze: Alinea.

Falcidieno Maria Linda (2006). Parola disegno segno. Comunicare per immagini. Segno, significato, metodo. Firenze: Alinea.

Gausa Navarro Manuel,Andriani Carmen, Fagnoni Raffaella (a cura di) (20 I 6). Med Net 03, Intelligent cities, resilience landscapes. Barcellona: Papersdoc.

Ippoliti Elena, Calvano Michele, Mores Lorenzo (20I4). 2.5D/3D Models for the enhancement of architectural-urban heritage. A Virtual Tour of design of the Fascist headquarters in Littoria. In ISPRS Annals of Photogrammetry, Remote Sensing \& Spatial Information Sciences, 2, pp. 189 - 196.

Ippoliti Elena, Meschini Alessandra, Moscati Annika, Rossi Daniele, De Luca Livio (20 I2). Shedding light on the city: Discovering, Appreciating and sharing Cultural Heritage using 3D Visual Technology. In Proceedings of I 8th International Conference opn Virtual System and Multimedia - VSMM. Milano, 2-5 September 2012, pp. I4I-148.

Leung Linda (2008). Digital Experience Design. Ideas, Industries, interactions. Chicago: Intellect Book - The University of Chicago Press.

Luigini Alessandro, Panciroli Chiara (20 I 8). Ambienti digitali per l'educazione all'arte e al patrimonio. Milano: Franco Angeli.

Ramella Francesco, Rostan Michele, (20 8). La terza missione degli accademici italiani: un quadro d'insieme. In Perulli Angela, Ramella Francesco, Rostan Michele, Semenza Renata (a cura di). La terza missione degli accademici italiani. Bologna: Editrice II Mulino, pp. 175-206.

Russo Michele, Guidi Gabriele (20I I). Reality-based and reconstructive models: digital media for cultural heritage valorization. In SClentific RESearch and Information Technology (SCIRES-IT), Vol. 2, CASPUR-CIBER Publishing, Pp. 7I -86.

Shedroff Nathan (200I). Experience Design I. Thousand Oaks: New Riders Publishing.

Torti Ruggero (2019). BEING POSITIVE, 02 Smart \& Slow Travel - New Responsive Landscapes. Milano: Franco Angeli.

\section{Autori}

Maria Linda Falcidieno, Scuola Politecnica di Genova, marialinda.falcidieno@unige.it

Massimo Malagugini, Scuola Politecnica di Genova, massimo.malagugini@unige.it

Ruggero Torti, Scuola Politecnica di Genova, ruggero.torti@unige.it

Per citare questo capitolo: Falcidieno Maria Linda, Malagugini Massimo,Torti Ruggero (2020). La comunicazione visiva nell'era digitale, tra diffusione e formazione/ Visual communication in the digital age, between diffusion and educational. In Arena A., Arena M., Brandolino R.G., Colistra D. Ginex G., Mediati D., Nucifora S., Raffa P. (a cura di). Connettere. Un disegno per annodare e tessere. Atti del $42^{\circ}$ Convegno Internazionale dei Docenti delle Discipline della Rappresentazione/Connecting. Drawing for weaving relationships. Proceedings of the 42 th International Conference of Representation Disciplines Teachers. Milano: FrancoAngeli, pp. $2121-2144$. 


\title{
Visual Communication in the Digital Age, between Diffusion and Educational
}

\author{
Maria Linda Falcidieno \\ Massimo Malagugini \\ Ruggero Torti
}

Abstract

The work deals with the issue of the potential arising from the use of new interactive technologies for representation; the reference is not only to their use for communication for recreational-tourist purposes, even if cultured, but especially for the dissemination of knowledge as for the design or training approach.

The field of reference, therefore, is that of University research and the consequent 'third mission', necessary so that specialist skills can be known and therefore acquired by as many interested parties as possible.

The field of exemplification is the territory, which is the most complex aspect of data collection and visualization. Today this is an unavoidable topic, which can call into question many anthropic works, which have upset the original layout of a place.

Representation -understood as an interactive visual contribution-appears as the ideal medium to immediately compare the original layout of a place - urban or suburban- which is no longer visible, because it has been transformed over time even in an evident way, according to two immediate aims: to support critical pre-project evaluations and to train citizens aware of the nature of their reference space. In this way the role of design disciplines will become that of an activity of public utility and a fundamental support.

Keywords

documentation, representation, new media, dissemination, training.

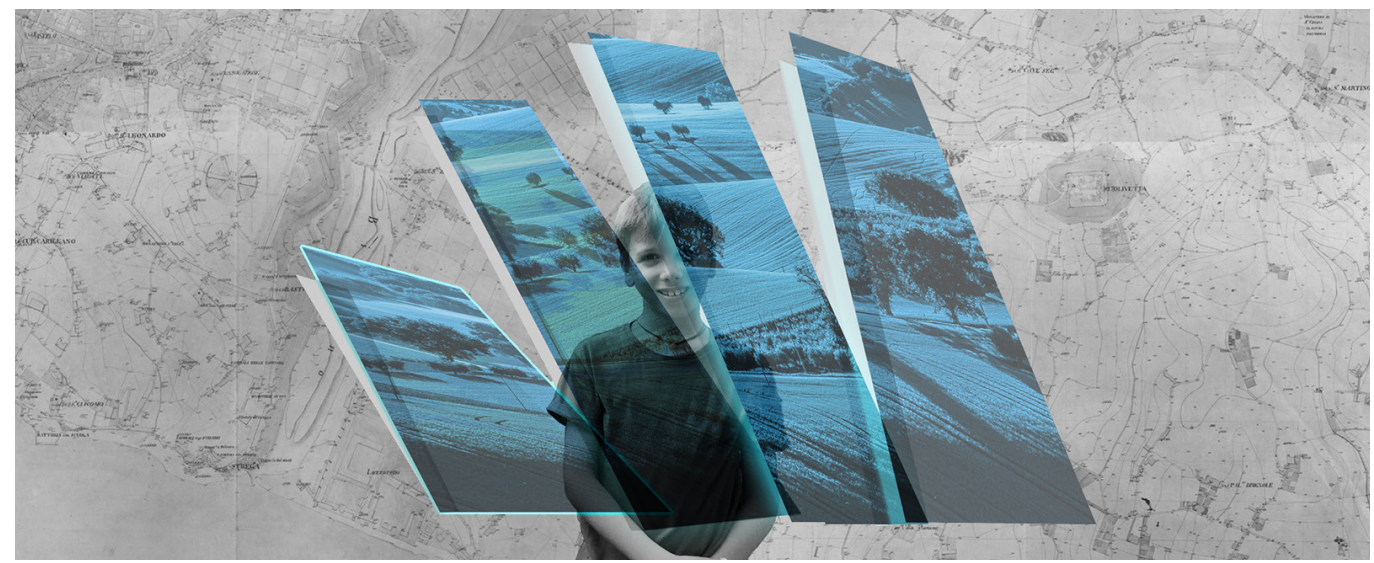




\section{Introduction}

If for some time nowadays the thought attributing to visual communication the role of the main alternative to textual communication has been consolidated -in a reality increasingly in need of common bases and shared codes for a facilitation of interpersonal and social relations - in part the interpolations between 'humanistic' and 'digital' contributions are still to be investigated. These are now inevitably in continuous contact and comparison.

Digital humanities is an oxymoron, which gives precisely the idea of the new frontiers that are emerging in the contemporary world; and which discipline more than representation (or drawing in a general sense as a graphic manifestation of reality or thoughts) can be identified with it?

From the 'humanistic': creativity, perception and subjectivity; from the 'digital': all the possible simplifications and expansions that continuously open new expressive, cognitive and applicative frontiers to representation and its multiple meanings. Today it seems necessary to better define some basic concepts, which can be useful to understand details, meanings, and operational areas.

One of the areas of greater and more profitable experimentation in this sense is given by the updating of the university world, through the new articulation of its mission: the first objective of the university is to transmit knowledge (linked to the progress of knowledge and, therefore, linked to research). For some time now, research and spreading of knowledge have reached full equality, and are leading to the training of teachers/researchers. But recently the objectives have become three: teaching, research and third mission. The third mission is still seen today with distrust and skepticism or is experienced and suffered as a depletion of knowledge and administrative coercion, as evidenced by the lack of specific literature related to its potential $[\mathrm{I}]$.

This contribution starts from some experiments carried out for research projects, which have resulted in applications relevant to the third university mission of communication, dissemination, cultural growth and self-training, opening of specialized knowledge to the com-

Fig. I. Setting the basic grid for the creation of the "puzzle" of comparison between the cartography of Ignazio Porro (c. 1835) and the orthophoto of the current state of the curthe Genoese territory.
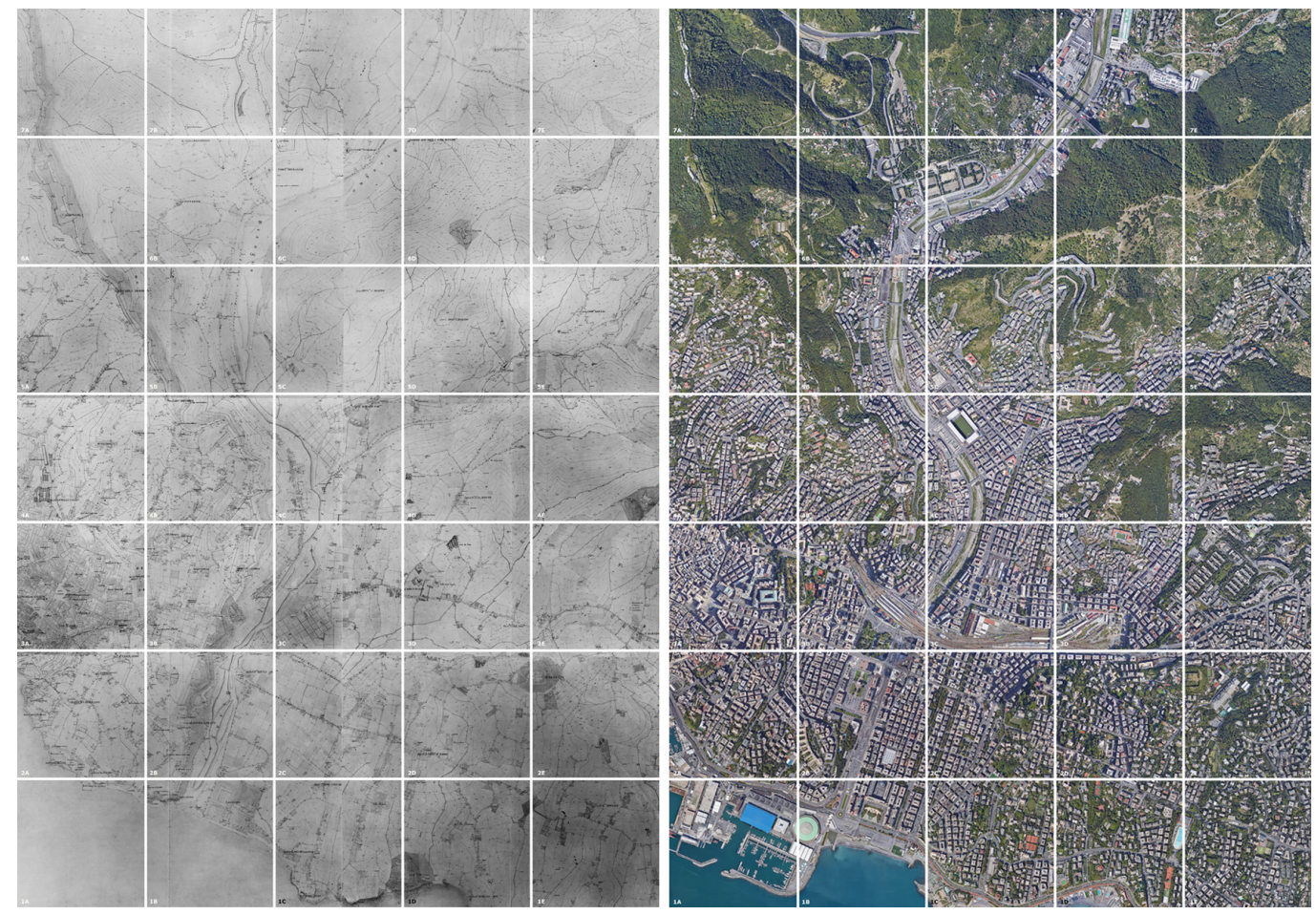
munity (community already in school, still in training or simply predisposed to knowledge). Interactivity is the common and transversal foundation. That is, the possibility to participate and contribute to the verification of effective and targeted forms of communication, with the consequent definition of target-specific visual languages, as well as the use of traditional and digital techniques; digital humanities are, therefore, configured as potential methodologies of general validity, shareable and reiterable in contexts also profoundly different from each other by content, based on the coexistence of suggestions and visual solicitations.

The first example refers to the collaboration that has been going on for some time with Protezione Civile and, more precisely, with the participation in the Science Festival that takes place every year in Genoa. In this venue, the dAD research group presented a project related to the dissemination of the knowledge of the territory of reference and its potential and fragility. From the analogical approach, to interactive multimedia participation (in the logic of digital humanities) to communicate to targets with different levels of schooling through targeted visual languages.

The second example is still linked to the interaction between the digital and the analogue and especially between the instinctive-subjective approach and the codified-objective approach. The field of action, this time, is a school or higher education target as it happens in the exhibition halls of Ansaldo Foundation, topic that is treated in the third paragraph, which is the starting point and the basis for the use of ICT in order to obtain a design fit to the requirements of the university mission about communication.

What emerges here is the non-trivialization of visual languages for the communication and dissemination of knowledge resulting from university research, obtained with a balanced and correct relationship between the two different approaches: not only divertissements that make the approach to knowledge more pleasant and easier, but real tools for work and study, involving by means of active and responsive participation. This is a fundamental act for a continuous verification by researchers of the correctness of their choices for the diffusion of knowledge.

Fig. 2. Identification of the reference elements for the superimposition and collimation of the cartography of lgnazio current cartography.
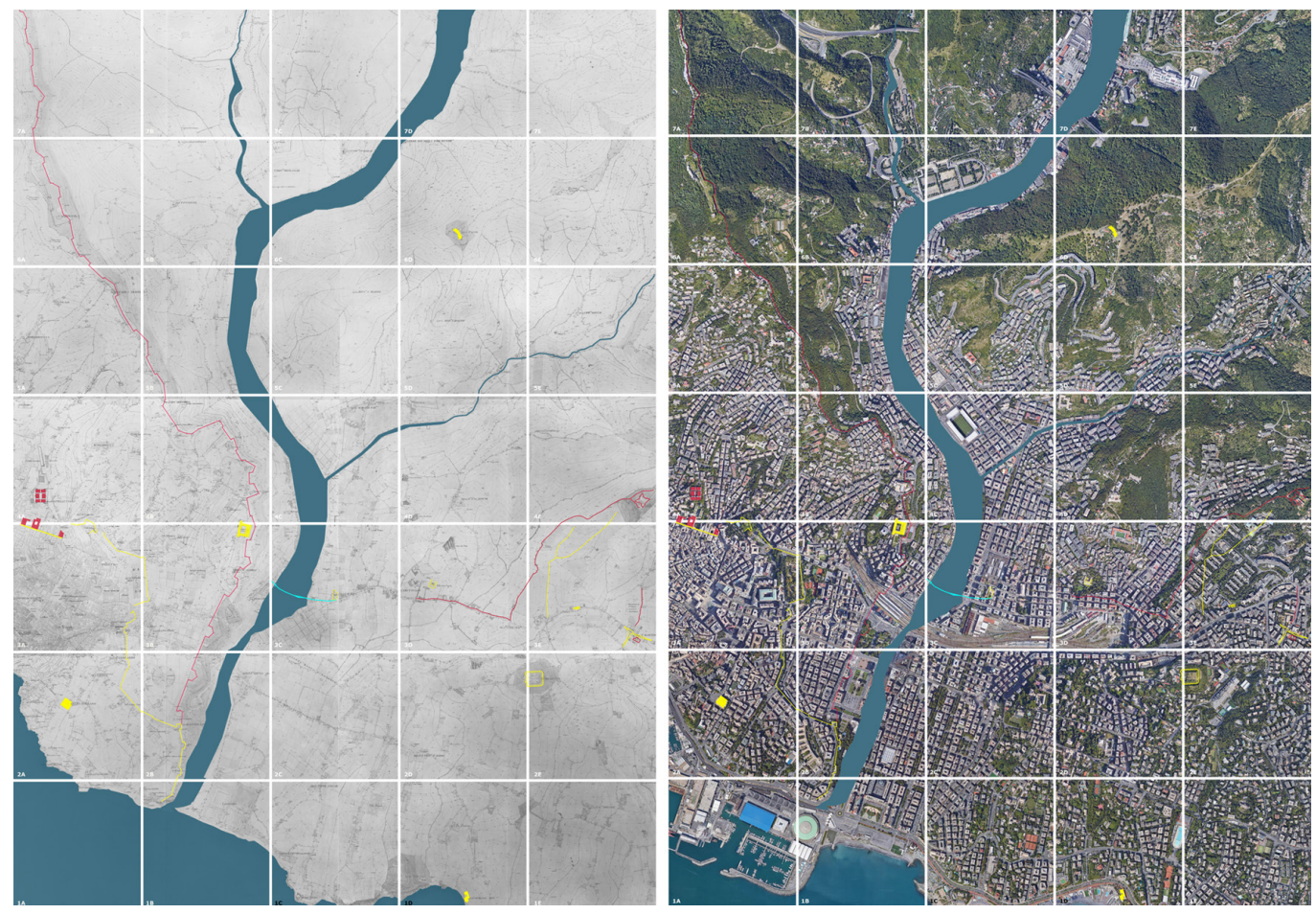


\section{Experience in civil protection}

The fruitful and continuous collaboration between the $\mathrm{dAD}$ (Department of Architecture and Design of the University of Genoa) and the Genoese Civil Protection Service has developed, in recent years, an effective communication system where drawing (always understood in a general sense as a graphic event) has played a role of primary importance [2]. The need to communicate the culture of Civil Protection to different targets (closely related to the knowledge of the territory, its fragility and resilience) together with the need to form an awareness of the good practices to be adopted in case of calamitous events, has further consolidated this collaboration calling into question a series of skills that -historically and institutionally- have always belonged to the disciplines of representation. In particular, reference is made to the representation of the territory, which has always made use of codes and graphic conventions in order to be able to immediately describe any kind of morphological or anthropic characteristics.

An extraordinary opportunity to give a concrete response to the third university mission (which has as its objectives communication and dissemination through specialized knowledge to spread culture) was the last edition of the Science Festival [3]. On that occasion the selected project developed a laboratory aimed at spreading awareness of how the city has evolved to the point of modifying its original natural layout. In this sense, representation has become the necessary means to visualize the mutations of the city and the territory. The experiences carried out in these years of collaboration with Protezione Civile have made it possible to organize an interactive laboratory-aimed not only at children-based on the recognition of places through cartographic and photographic representation according to a chronological path that highlights the evolutionary and expansive process of the city and territory.
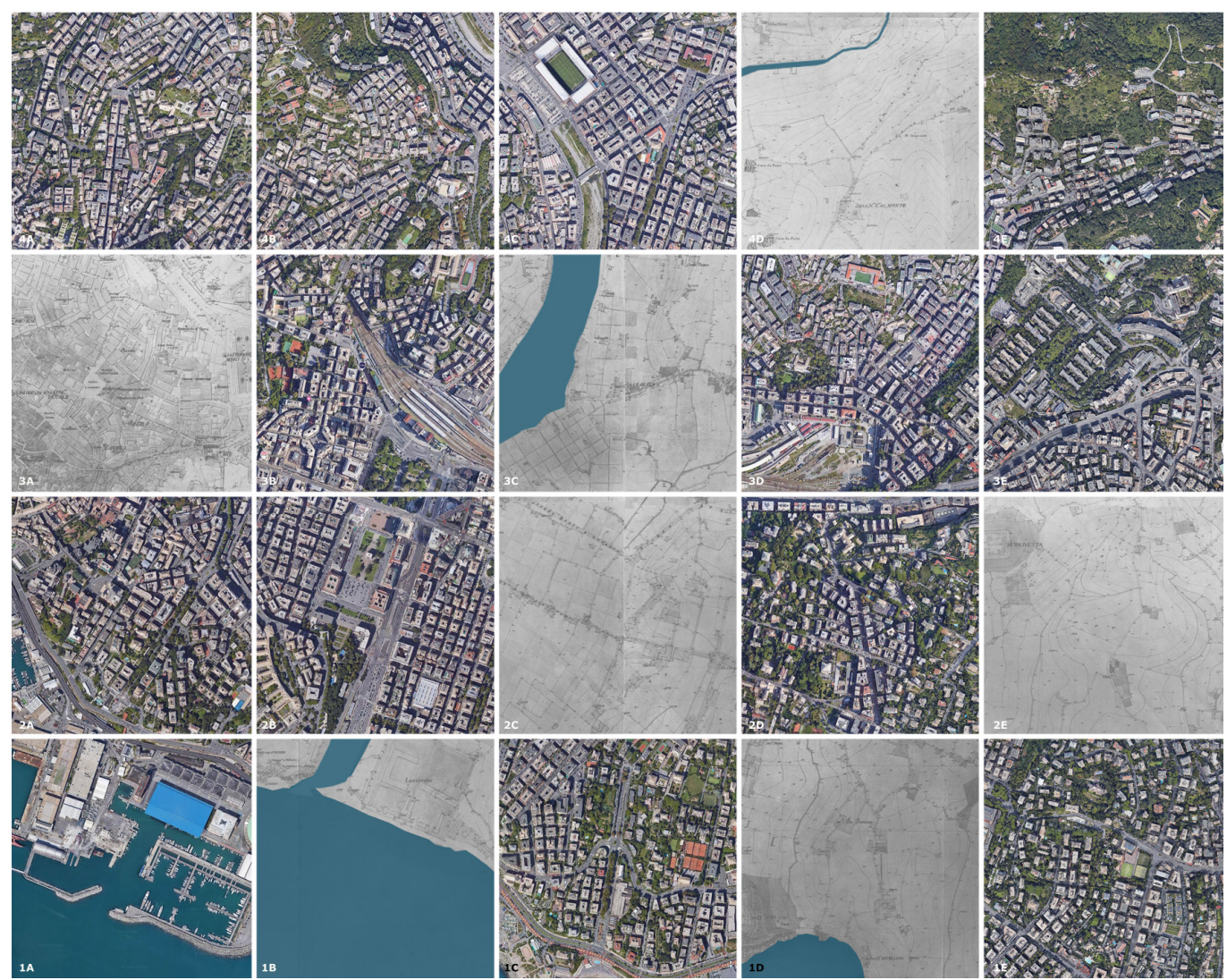
In order to achieve this objective, the traditional systems of cartographic representation were used: a large carpet was created on which an enlargement of the representation of the city was printed according to Ignazio Porro's topographic survey of the first half of the nineteenth century [4]; a transparent sheet of paper with some features of the morphology of the territory first superimposed on it, and then a real puzzle whose tiles recomposed the current orthophotographic image of that same territory. The superimposition of the tiles depicting the current state on the historical cartography has made it possible to visualize with immediacy the great anthropic interventions that have modified the urban and territorial planning causing, in some cases, the loss of the original identity of the places and, in others, altering the natural resilience of the territory itself. The laboratory has made it possible to understand how the anthropization of the territory necessarily implies an awareness of the possible consequences that could derive from it and, therefore, to understand what further actions are necessary to implement in particular circumstances or calamitous events. The experimental approach to this type of didactic-laboratory activity has opened up a line of research that makes use of current digital tools to provide increasingly specific and detailed information, up to the reading of the individual territorial components, whether natural (watercourses now covered), architectural (buildings transformed or replaced over time), productive (areas now disused). In a more general sense, it is a matter of extending this type of critical reading of the territory through its interactive representation to a wider pool of users (not only schools, but institutions, other training bodies etc.) using digital systems that, starting from the virtual representation of the current state of the city, can immediately visualize its evolutionary process, describing a sort of time-lapse of the evolution of the city and its territory, modulated in relation to the different needs of the user in question. It will be possible, then, to visualize in detail some phases of the entire evolutionary process; to view the mutations of a particular portion of the territory; to carry out at any time a comparison with the most evolved phase (current state), until projecting the possible mutations that are still in progress: in short, it will be possible to provide the vast number of operators involved with a tool that is easy to use, but of high cognitive and operational potential, useful to verify and answer design questions.

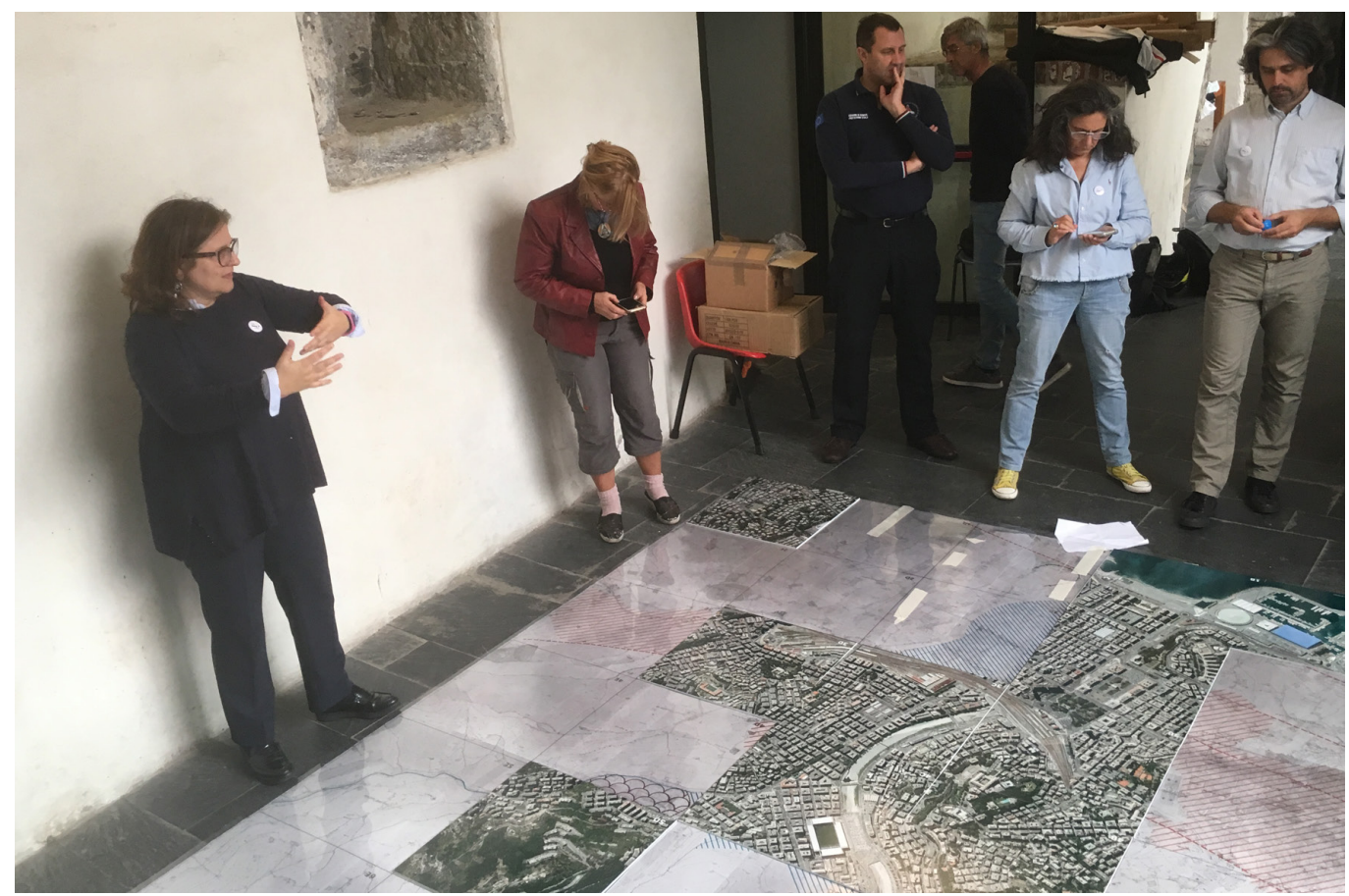




\section{Experience: new opportunities to represent}

From what has been stated so far on the concept of integration of analogical and interactive systems, it emerges that the contemporary debate on the potentialities induced by the continuous technological evolutions leads more and more to the search for the integration of AVC systems (Audio, Video and Controls), Lighting, ICT Networking. This hybridization is the object, therefore, of a growing attention from direct and indirect interlocutors who -even without having specific knowledge and technological skills of the issues- are involved in the system, looking for new opportunities and different ways of representing for targeted purposes. It is a matter of knowing the past to plan the future, to inform and form a society aware of the potential and risks of the territory to which it belongs and to generate experiences.

The objective here is not, therefore, to define and disseminate the technical characteristics, protocols, formats and resolutions present in the most current and sophisticated technologies at the service of representation but, on the contrary, to disseminate the potential that these technologies are able to offer, to implement and, above all, to inspire solutions for situations even problematic ones in continuous evolution. These innovative digital frontiers of visual communication are capable, in fact, of devising new ways of visualizing the context and generating interaction among users and the technologies themselves, in an extremely ductile way with respect to the purposes, which can also be very different from each other. Hence the decision to share two concrete experiences to be lived in first person both as protagonists and as end users.

In this regard, the two application examples (the multimedia room of Ansaldo Foundation in Genoa [5] and the representation of 3D content through holographic projections) are parts of a research path and in-depth studies expressed both during the Master and PhD, and during the recent teaching experience in China at the Beijing University of Chemical Technology [6]. In their communicative diversity, these two experiences are united by the high technological content and the capacity for immediate interaction.

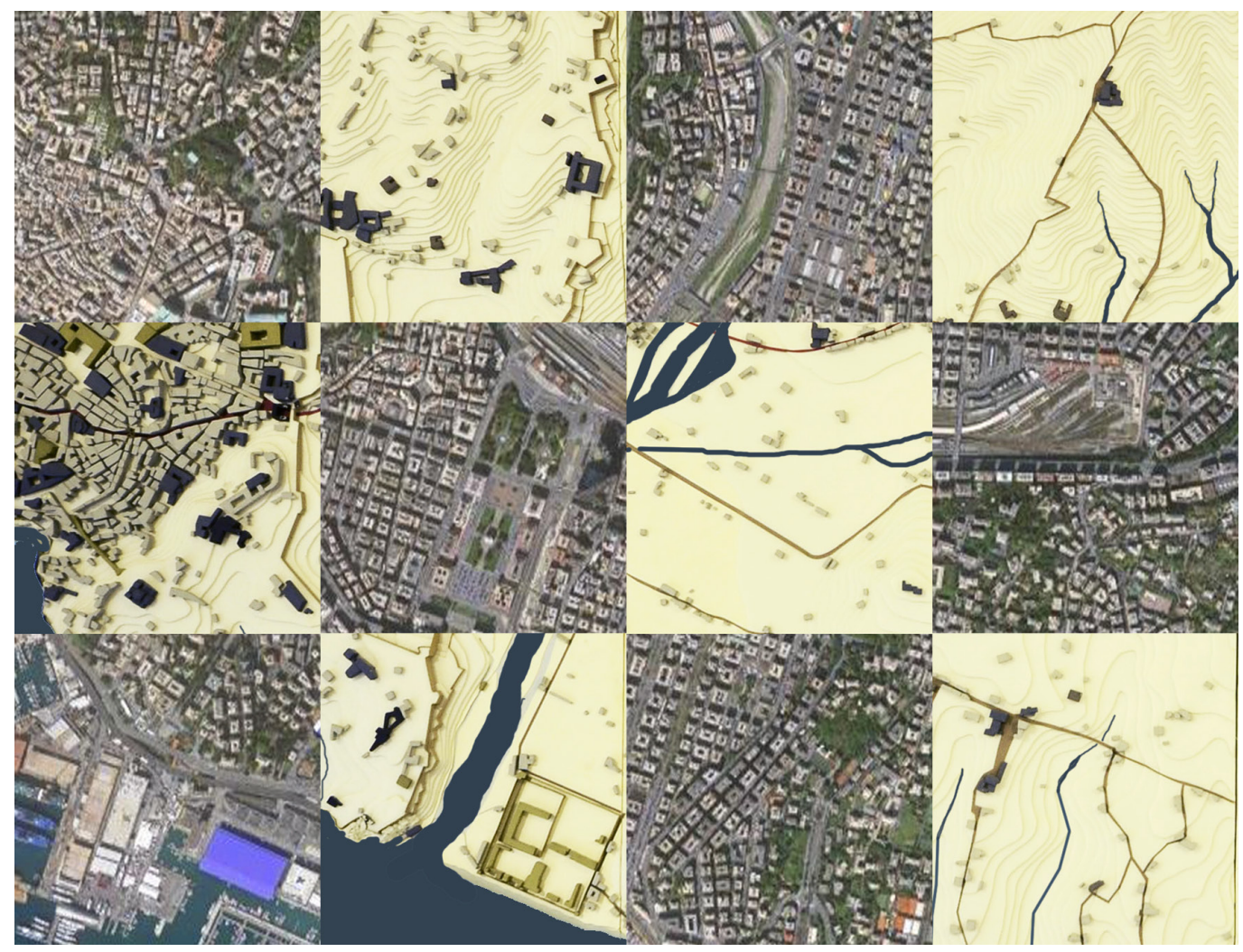


Specifically, the multimedia installation at the headquarters of the Ansaldo Foundation in Genoa uses video projection on a large screen of archival images that tells the change of a glimpse of Genoa's territory through a video representation of great impact, capable of transposing into visual language the intrinsic value of documents, stories and contexts. The user is enveloped in an evocative setting -deliberately poorly lit due to technical requirements- characterized by the presence of a sophisticated video projection system and a series of flashlights available to visitors. The passage of the beam of the flashlight controlled by the user, makes the historical black and white photographs (which characterize the urban landscape of the twentieth century) give way to the colourful and current photographs of the same places perfectly superimposed on the previous ones, highlighting the differences among the images belonging to the past and the current and real appearances of the city. The passage of the light beam, in fact, cancels the projection of the historical image -as it is sensitive to light-cancelling its contents; only in that precise portion of the area illuminated by the torch, therefore, the colour image is present on a level below highlighted.

The second experience, instead, is linked to the recent technological revolution at the service of digital creativity able to offer countless possibilities: Pixel Mapping, based on the control of lights, led strips and sophisticated hardware and software equipment to achieve the interaction between the third dimension and lighting. This technique is based on the translation of information from pixels to RGB; as in holographic representation techniques designed to reproduce fluctuating $3 \mathrm{~d}$ holograms, the controlled spatial placement of lights, generating the three-dimensional component, plays a fundamental role. The holographic display, in fact, is a device consisting of a rotor with four blades on each of which is placed a strip of LEDs that, turning at high speed, can reproduce holograms in motion. The only needs are to have the App and match the holographic projector to your device to allow the dialogue and the Wi-Fi transmission of the contents to the holographic display. The information we want to generate and then transmit to the holographic projector-regardless of whether it is text, images, video, or 3D virtual models- requires saving in .jpeg, .mp4, .mov and other standard formats. The individual devices can be installed on the wall, ceiling, floor or embedded in totems. The union of several rotors forms a 'wall' capable of obtaining larger $3 \mathrm{~d}$ holograms with high resolution, capable of generating immersive experiences.

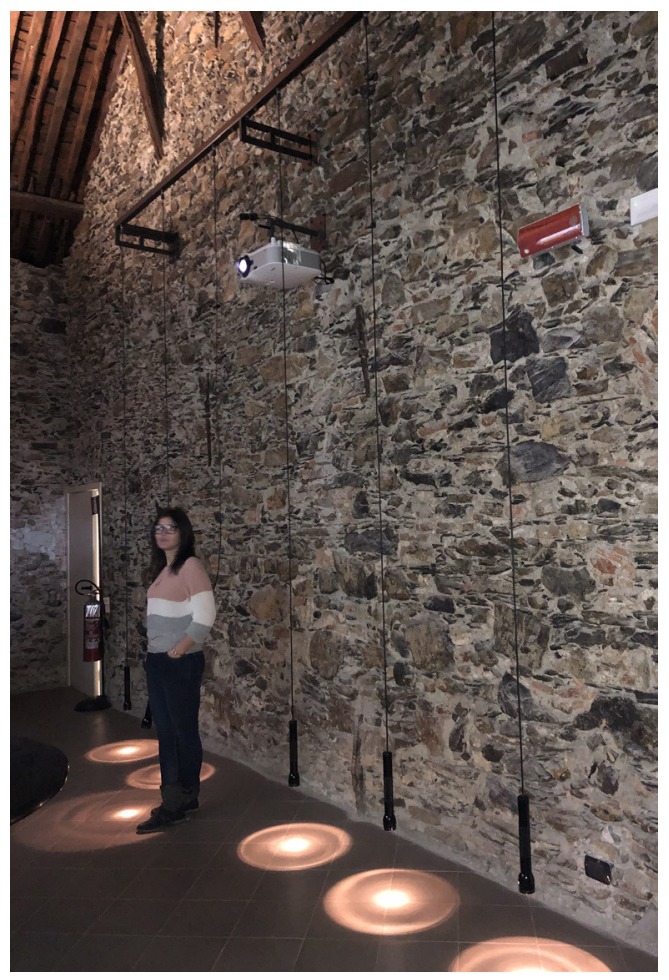




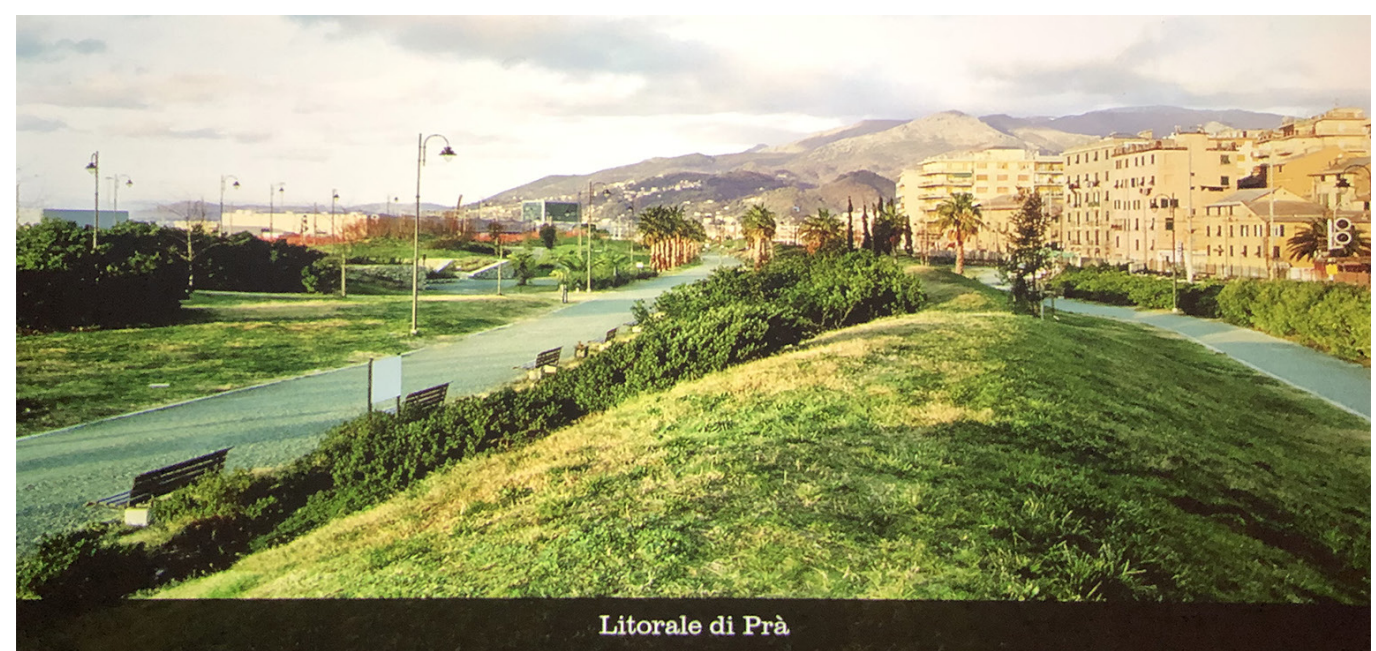

Fig. 7. Sequence of images projected on a large

screen that tell the

the territory through a

high-impact vid
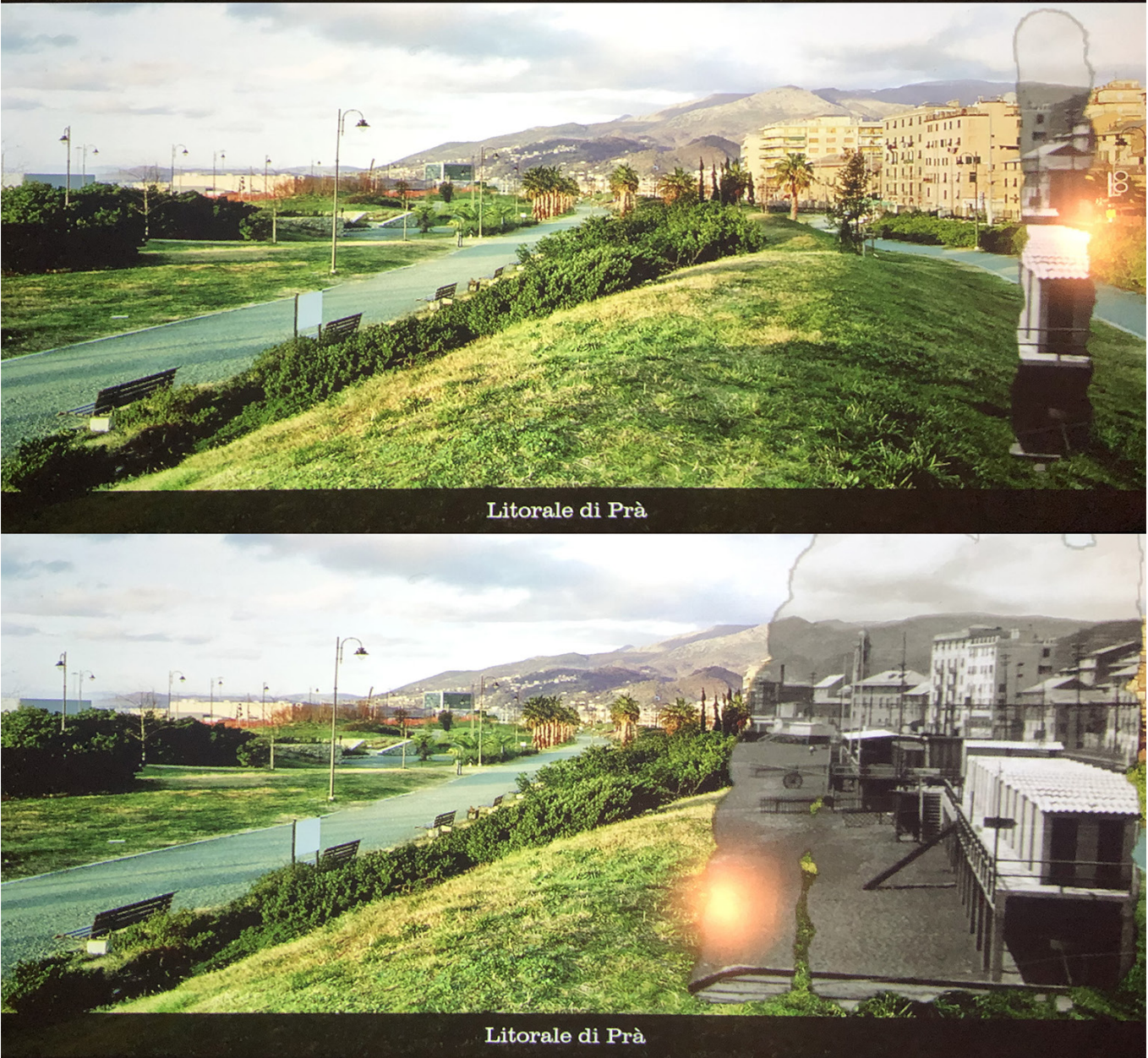


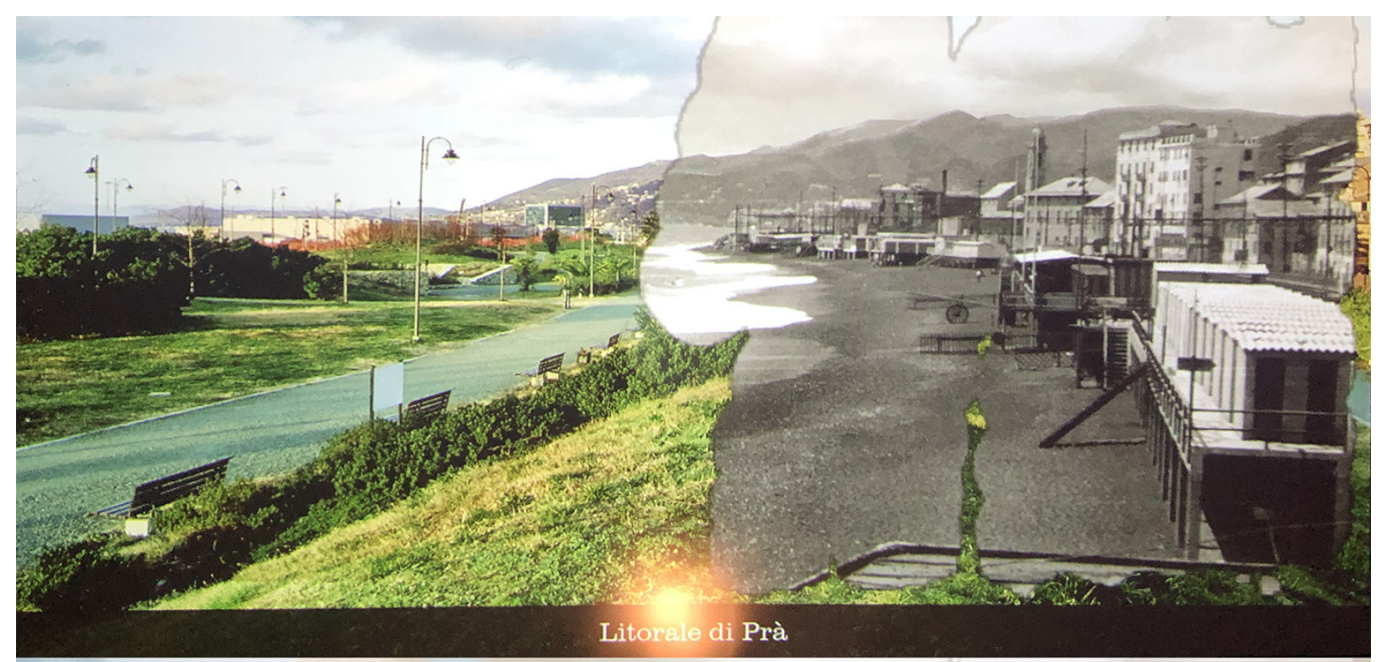

Fig. 8. The light beam emitted by the flashlight controlled by the user cancels the current color photographs, making a photographs, making a glimpse of the historica black and white images connoting the twentieth
century urban landscape of the same places.
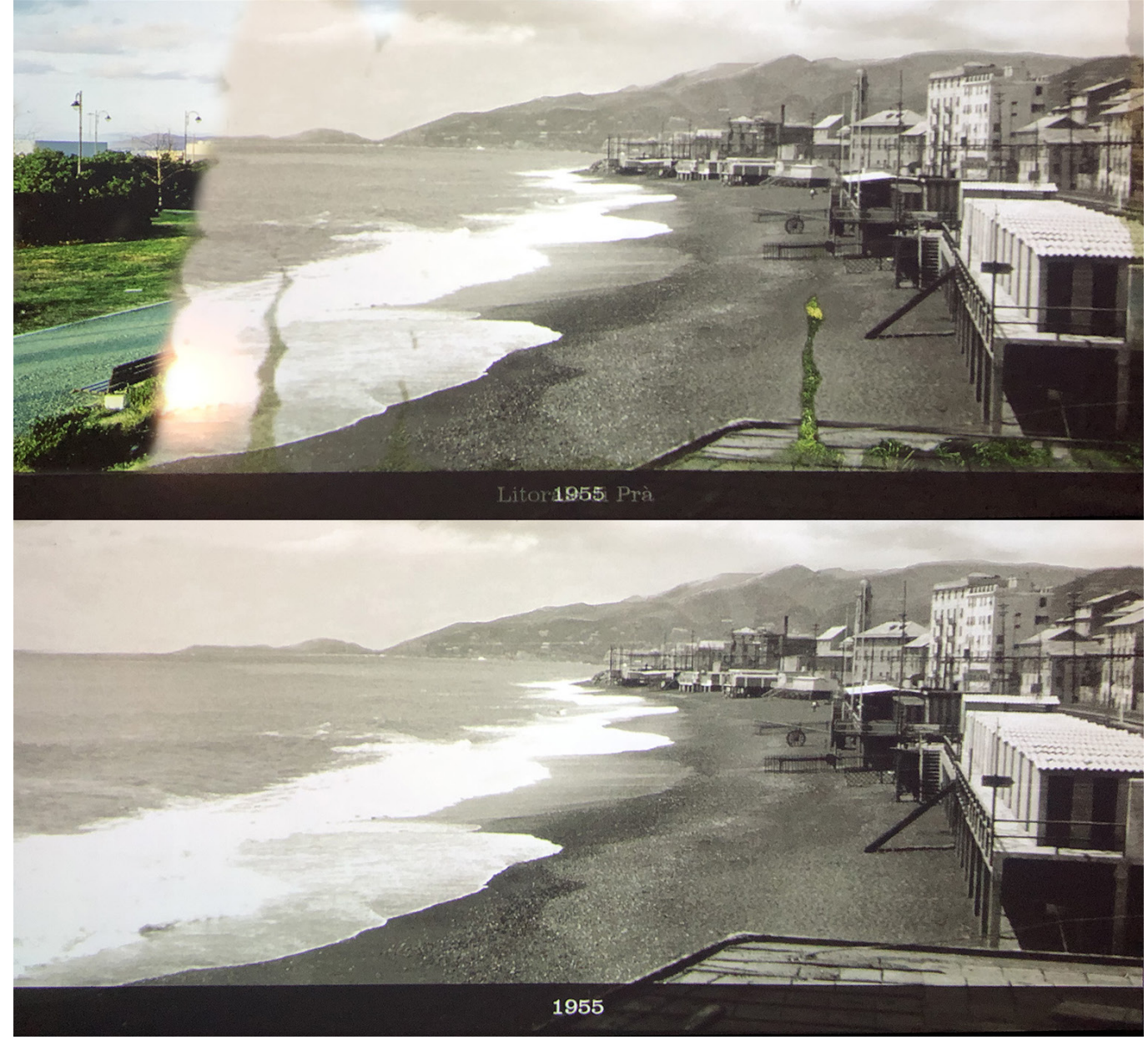
Fig. 9. Sequence of images representing an assembly phase of a holographic display consisting of a four-blade rotor on each of which there is a strip Of LEDs, the union of several Wall rotors capable of obtaining larger 3d holograms; the user interface of the App downloaded to your smartphone and combined with the holographic projector for the WiFi transmission of the $3 d$ content to be projected.

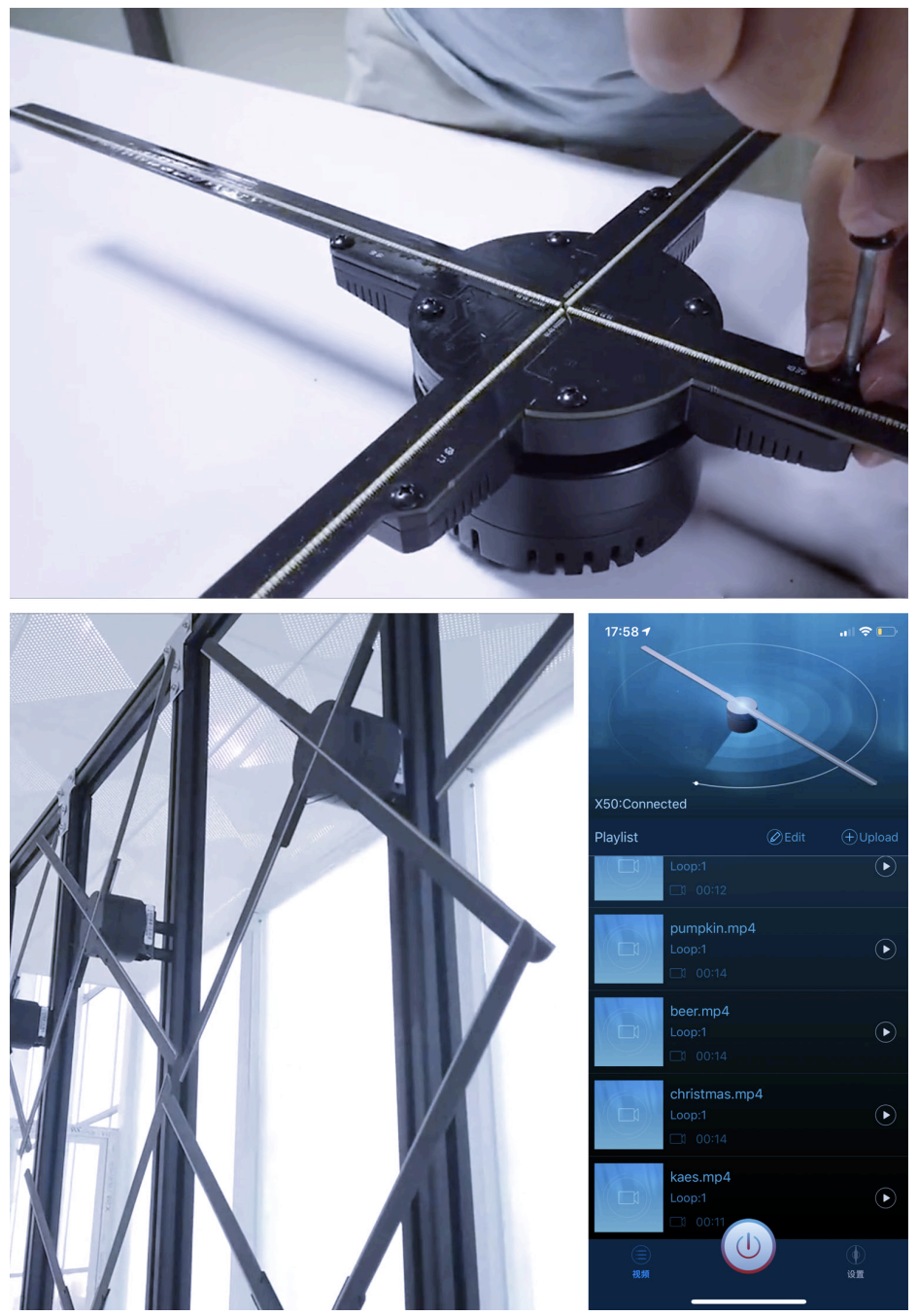

The strength of these forms of representation -whether interactive or immersive- lies in the involvement of the user and makes these technologies versatile and highly communicative, capable of promoting knowledge at various levels. Specifically, they allow to approach the territory in a critical way to produce knowledge even in those who do not know its past, thus training potential operators and conscious users.

In conclusion, we are users and creators of an increasingly advanced technological progress, proponent of an epoch-making change in representation techniques for the dissemination of information that, while flanking traditional methods and tools (based on three-dimensional display through two-dimensional media such as monitors), impose themselves on the scene through digital devices capable of reproducing holographic 3d content of considerable impact in the real world, perceptible without the aid of special devices. The importance of such a possibility can be understood if we think about the need to form groups of people, to illustrate limits and potentialities in view of design interventions or to make people understand the fragility of an apparently solid territory.

The direct experiences of multimedia techniques and their potential can therefore be summarized in a keyword: Experience [7], as the beginning and source of inspiration for new projects, produced by the evolution of the sector and the change in today's increasingly connected and supported by information technology. 

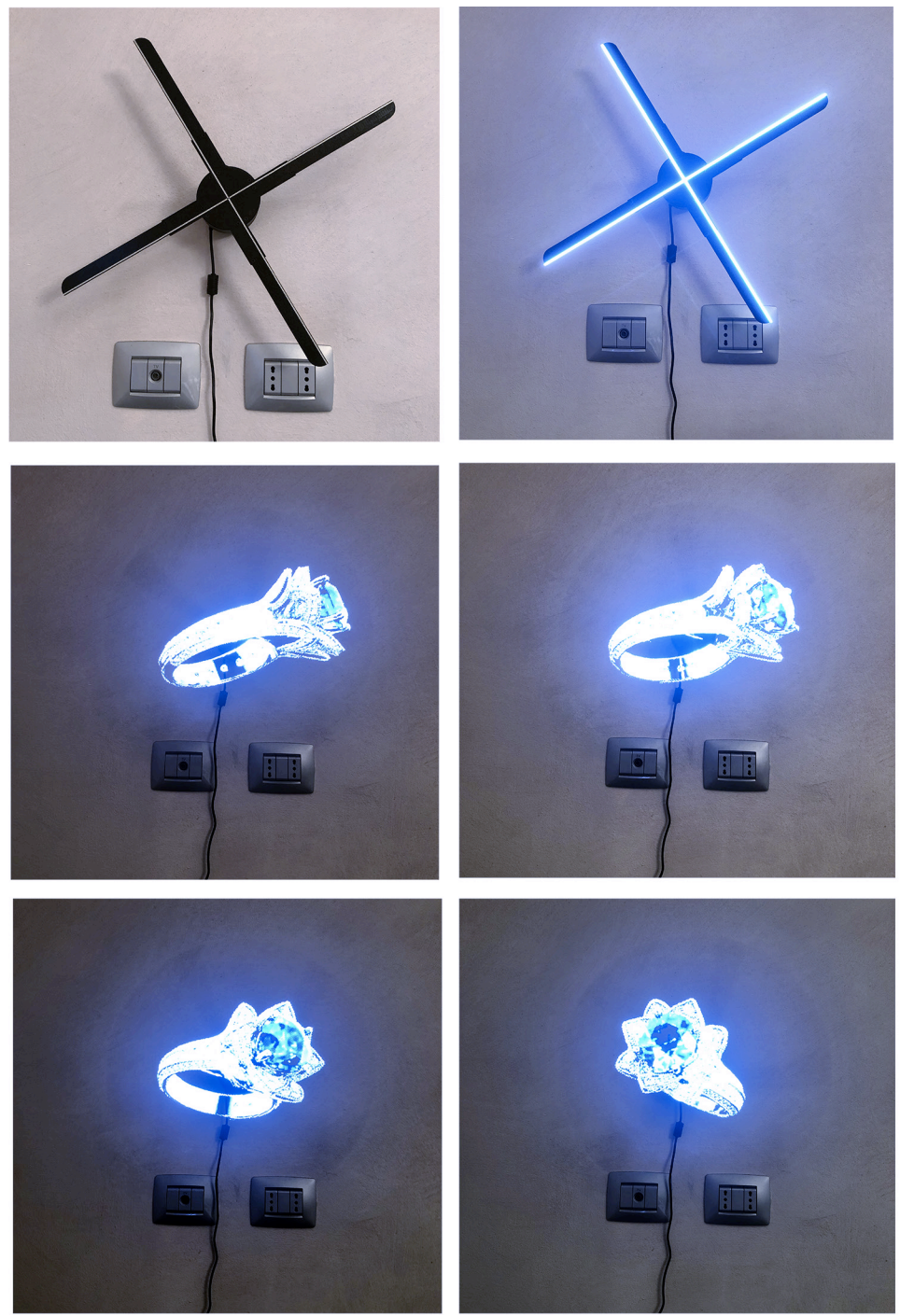

Notes

[I] While there is no doubt about the lack of specific scientific treatment on the mission about communication, it should be noted that many ideas and considerations stem from the rich and articulated literature concerning the contribution of new interactive technologies applied to cultural heritage, as well as experiments with communications for cultural purposes via virtual reality, augmented or mixed (see bibliography), re-read and interpreted according to the university's specific purpose.

[2] The long-term collaboration between the Department Architecture and Design of the University of Genoa and the Civil Protection Service of the City of Genoa has started from the need to define and promote a recognizable visual identity for communication of public utility. The research work has found application in the numerous communication campaigns and in the planning and realization of a series of events aimed at distinct targets and has been partly published in the book Emergenze ambientali e sociali: nuovi modelli di comunicazione visiva, Genova University Press, 2019.

[3] The Science Festival is organized by the City of Genoa and this year will reach its I 8th edition. The festival is a reference point for the dissemination of science, as well as an opportunity for researchers, enthusiasts, schools and families to meet, thanks to a series of meetings, workshops, shows and conferences to tell the science in an innovative and engaging way, with interactive and transversal events. To date it is considered one of the largest events for the diffusion of scientific culture at an international level.

[4] Innazio Porro's cartography, made on the basis of the instrumental survey carried out in the 1830s, represents an extraordinarily reliable instrument for the knowledge of the Genoese territory (and its buildings) before the great urban upheavals of the 19th century.

[5] The experience of Fondazione Ansaldo dates to 2004 and led to the verification of the effectiveness of the technique used by study N! 03- based on an infrared light system detected by a special software -but also to the problem of maintenance and updating, once the relationship with operators-designers has been closed; therefore, the subject of current research is the possibility of transforming the layout - result of a program no longer on the market - into a similar one, but supported by hardware and software compatible with internal management within the Company. 
[6] The interaction between digital and analogue and the innovative technological frontiers of visual communication were the subject of discussion, research and comparison during the university Master's Degree: Creative Writing and production of digital content at the University of Genoa and in the Transversal Seminars: Analog and digital models: tools and methods for digital communication, carried out within the Doctoral School in Architecture and Design, of the Polytechnic School and From analog to digital. Representation at the service of visual communication carried out in the context of Digital Humanities Communication and new media, Campus of Savona, University of Genoa.

[7] This definition derives from the concept of experience design attributable to Nathan Shedroff, who supports the importance of technological interaction and the integration of systems capable of generating meaningful and emotional experiences [Shedroff $200 \mathrm{I}$ ].

\section{References}

Apollonio Fabrizio Ivan (2012). Architettura in 3D. Modelli digitali per i sistemi cognitivi. Milano: Bruno Mondadori.

Brusaporci Stefano (2018). Advanced Mixed Heritage: A Visual Turn Through Digitality and Reality of Architecture. In International journal of computational methods in heritage science, vol. 2, pp. 40-60.

Calvano Michele, Wahbeh Wissam (20/4). Disegnare la Memoria. L'immagine della città attraverso la rappresentazione integrata - Drawing the Memory. The image of the city through the integrated representation. In DisegnareCon, vol. 7, n. I3, pp. $1-12$.

di Luggo Antonella, Zerlenga Ornella., Pascariello Maria Ines (2016). Rappresentazione e comu- nicazione del paesaggio tra tradizione e innovazione. In Capano Francesca, Pascariello Maria Ines, Visone Massimo (a cura di). Delli Aspetti de Paesi-Vecchi e nuovi Media per l'Immagine del Paesaggio, Vol II. Napoli: Cirice.

Falcidieno Maria Linda (2009). Comunicazione e rappresentazione. Firenze: Alinea.

Falcidieno Maria Linda (2006). Parola disegno segno. Comunicare per immagini. Segno, significato, metodo. Firenze: Alinea.

Gausa Navarro Manuel, Andriani Carmen, Fagnoni Raffaella (a cura di) (2016). Med Net 03, Intelligent cities, resilience landscapes. Barcellona: Papersdoc.

Ippoliti Elena, Calvano Michele, Mores Lorenzo (20I4). 2.5D/3D Models for the enhancement of architectural-urban heritage. A Virtual Tour of design of the Fascist headquarters in Littoria. In ISPRS Annals of Photogrammetry, Remote Sensing \& Spatial Information Sciences, 2, pp. 189-196.

Ippoliti Elena, Meschini Alessandra, Moscati Annika, Rossi Daniele, De Luca Livio (20 I2). Shedding light on the city: Discovering, Appreciating and sharing Cultural Heritage using 3D Visual Technology. In Proceedings of I 8th International Conference opn Virtual System and Multimedia - VSMM. Milano, 2-5 September 20 I2, pp. I 4 I-148.

Leung Linda (2008). Digital Experience Design. Ideas, Industries, interactions. Chicago: Intellect Book - The University of Chicago Press.

Luigini Alessandro, Panciroli Chiara (20 I 8). Ambienti digitali per l'educazione all'arte e al patrimonio. Milano: Franco Angeli.

Ramella Francesco, Rostan Michele, (20I8). La terza missione degli accademici italiani: un quadro d'insieme. In Perulli Angela, Ramella Francesco, Rostan Michele, Semenza Renata (a cura di). La terza missione degli accademici italiani. Bologna: Editrice II Mulino, pp. I 75-206.

Russo Michele, Guidi Gabriele (201 I). Reality-based and reconstructive models: digital media for cultural heritage valorization. In SClentific RESearch and Information Technology (SCIRES-IT),Vol. 2, CASPUR-CIBER Publishing, Pp. 7I -86.

Shedroff Nathan (200I). Experience Design I.Thousand Oaks: New Riders Publishing.

Torti Ruggero (2019). BEING POSITIVE, 02 Smart \& Slow Travel - New Responsive Landscapes. Milano: Franco Angeli.

\section{Authors}

Maria Linda Falcidieno, Scuola Politecnica di Genova, marialinda.falcidieno@unige.it

Massimo Malagugini, Scuola Politecnica di Genova, massimo.malagugini@unige.it

Ruggero Torti, Scuola Politecnica di Genova, ruggero.torti@unige.it

To cite this chapter. Falcidieno Maria Linda, Malagugini Massimo, Torti Ruggero (2020). La comunicazione visiva nell'era digitale, tra diffusione e formazione/Visual communication in the digital age, between diffusion and educational. In Arena A., Arena M., Brandolino R. G., Colistra D., Ginex G., Mediati D., Nucifora S., Raffa P. (a cura di). Connettere. Un disegno per annodare e tessere. Atti del $42^{\circ}$ Convegno Internazionale dei Docenti delle Discipline della Rappresentazione/Connecting. Drawing for weaving relationships. Proceedings of the 42 th International Conference of Representation Disciplines Teachers. Milano: FrancoAngeli, pp. 21 | 8-2 141. 